\title{
THE POST-LARVAL SAND EELS (AMMODYTIDAE) OF THE CELTIC SEA AND PLYMOUTH AREA
}

\author{
By P. G. Corbin, B.A. \\ Zoologist at the Plymouth Laboratory \\ and Vidya Vati, M.Sc. \\ Indian State Scholar, Lucknow University
}

(Plates I \& II and Text-figs. I-6)

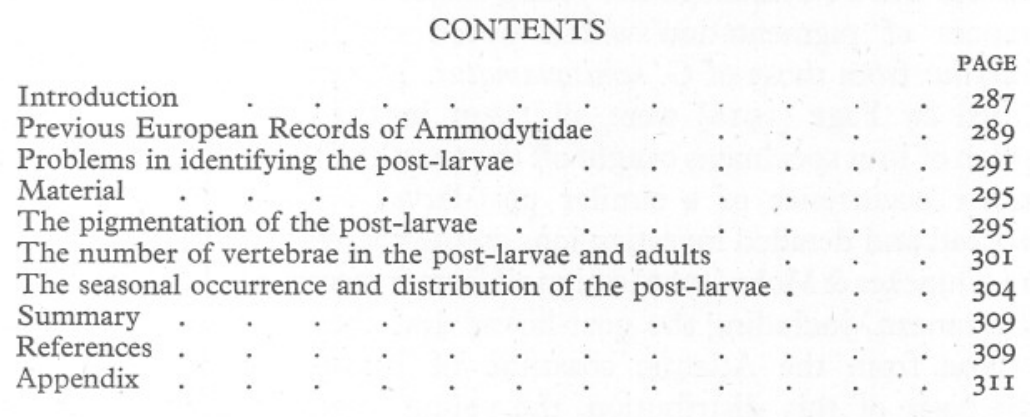

\section{INTRODUCTION}

The young stages of certain species of sand-eels (Ammodytidae) can be distinguished by differences in their pigmentation. Ford (I920) has described the post-larvae of Ammodytes lanceolatus Lesauvage and A. tobianus $\mathrm{L}$. The post-larva of $A$. marinus ${ }^{\star}$ Raitt has been identified by Kändler (I94I), and Fage (19I8) has given an account of the post-larva of Gymnammodytes cicerellus (Rafinesque). In addition to post-larvae of lanceolatus, tobianus and marinus, a fourth Ammodytes post-larva, with a pigmentation pattern distinct from those of the above four species, has been found in collections from the Celtic Sea and Plymouth area.

The occurence of four Ammodytes post-larvae in this area is of particular interest in relation to the observations of Kändler (I94I), who also found four Ammodytes post-larvae in the southern North Sea and Baltic. He records post-larvae of lanceolatus, marinus and two forms of tobianus, a spring brood form and an autumn brood form, both differently pigmented. These Kändler refers to two races of tobianus which he is able to distinguish in the

* Duncker \& Mohr (1939) do not accept A. marinus as a separate species. The identification of the post-larva by Kändler (I94I) and the specific scale distribution pattern in the adult (paper in manuscript, P.G.C.) leave no doubt, however, that it is a valid species, distinct from A. tobianus. 
adults-the spring spawners and the autumn spawners. The pigmentation of the fourth Ammodytes post-larva from Plymouth and the Celtic Sea agrees very closely with the description of the pigmentation of the autumn-brood tobianus post-larva from the North Sea and Baltic (Kändler, I94I, p. 66).

The fourth post-larva from the Celtic Sea and Plymouth area is also of interest in relation to the four species of adult Ammodytidae ( $A$. lanceolatus, A. tobianus, A. marinus and G. semisquamatus (Jourdain)) recorded by Raitt (1934, I935) in Scottish waters. In this connexion, it is to be noted that Duncker \& Mohr (1935, I939), in their revision of the Ammodytidae, placed the smooth sand eels in a new genus, Gymnammodytes, and divided the former single European species, A. cicerellus, into two species, G. cicerellus and $G$. semisquamatus. It may be anticipated from this division that specific differences will be evident in the young stages of these two species, including differences of pigmentation which would distinguish the post-larvae of $G$. cicerellus from those of $G$. semisquamatus. The young stages of $G$. cicerellus described by Fage (I9I8) were all taken in the Mediterranean, with the exception of four specimens caught off the mouth of the River Tagus, Portugal. No other occurrence of a similar post-larvae is recorded throughout the widespread and detailed investigations on the young fish of European Atlantic waters. Duncker \& Mohr (I939) assign all former records of $A$. cicerellus from the Mediterranean, including the post-larvae described by Fage, to G. cicerellus, and those from the Atlantic coastline of Europe to G. semisquamatus*. On the basis of this distribution, the young stages of G. semisquamatus, if separable by differences of pigmentation according to the above inference, have not hitherto been captured or identified.

There seemed then at the outset to be two possible interpretations of the fourth Ammodytes post-larva from the Celtic Sea and Plymouth area. It might belong to the Atlantic $G$. semisquamatus which is known from Raitt's records of the adult to be abundant in the north-east Atlantic. Or, to judge from its close resemblance to Kändler's autumn brood tobianus post-larva, it might belong to Ammodytes tobianus. In this latter event there would then be two forms in the south-western area as well as in the North Sea and Baltic.

The present study leads, however, to the conclusion that neither of these two possible interpretations applies, and that the fourth post-larva from the Celtic Sea and Plymouth area, although undoubtedly belonging to the family Ammodytidae, is not attributable to a known species.

Before discussing the evidence which leads to this conclusion, it will be relevant briefly to review some of the previous literature.

* A strict interpretation of this would ascribe the four post-larvae caught off the mouth of the Tagus to G. semisquamatus. Fage, however, considered them to belong to the series of young stages of $G$. cicerellus taken in the Mediterranean. But it must be recalled that this was before Duncker \& Mohr's separation of the two species. 


\section{PreVIOUS EUROPEAN RECORDS OF AMMODYTIDAE}

In addition to the two commonly known British species, Ammodytes lanceolatus and A. tobianus, Raitt (1934, 1935) recorded Gymnammodytes semisquamatus and a new species, A. marinus. He found marinus to the north and west of Scotland and in the North Sea in greater abundance than any of the other three species. It is now also known to occur in the Irish Sea off the Isle of Man*, in addition to the present records of the young stages from the Celtic Sea and off Plymouth. Adult marinus have not, however, been taken in the southwestern area. Raitt also found G. semisquamatus in very considerable numbers to the north and west of Scotland, but less commonly on the east coast and in the open North Sea. Before this discovery of the abundance of this species in Scottish waters, it was considered to be restricted, with the exception of a very few isolated records from northern waters (Shetlands, one specimen as $A$. siculus, Günther, 1867: Southern Norway, five specimens as $A$. cicerellus, Collett, 1904; Grieg, I912: Sweden, Lönnberg, 1915), to the St Malo region in the southern half of the mouth of the English Channel (Jourdain, I879; Moreau, I89I), the Atlantic coastline of France (Acloque, I900), Portugal and Spain (de Buen, 1935). It has recently been found in the Irish Sea ${ }^{\star}$ and in the English Channel off Plymouth ${ }^{\star}$. It did not occur in the extensive collections made by Kändler (I94I) in the Baltic and southern North Sea although it is recorded by Poll (1947) from the latter area. The distribution of the adults of the European Ammodytidae may be summarized from the above records and those of other authors:

A. lanceolatus. Iceland ${ }^{1,2}, \dagger$ Norway $^{3}$, Faroes ${ }^{1,2}$, Baltic $^{4}$, North Sea $\mathrm{S}^{4,5,6}$, west coast of Ireland ${ }^{6}$, Irish Sea ${ }^{7}$, English $\mathrm{Channel}^{6}$, France (Biscay) ${ }^{8}$, Spain (Biscay) ${ }^{9}$, Portugal (south to mouth of River Tagus) ${ }^{10}$; very rarely found in Mediterranean ${ }^{6}$, not recorded from Spanish Mediterranean coast ${ }^{9}$.

A. marinus. Greenland ${ }^{1,2}$, Iceland ${ }^{1,2}$, Norway $^{11}$, Faroes ${ }^{1,2}$, Baltic $^{4}$, North $\mathrm{Sea}^{4,5}$, Irish Sea ${ }^{12}$; not recorded from west coast of France, Spain, Portugal, or from Mediterranean.

The present distribution records of marinus post-larvae have a southern limit in the mouth of the English Channel (pp. 307-9), and consequently the possibility of the species occurring even farther to the south cannot be excluded.

A. tobianus. Greenland (one specimen) ${ }^{1}$, Iceland ${ }^{1,2}$, Norway ${ }^{11}$, Faroes ${ }^{1,2}$, Baltic ${ }^{4}$, North Sea ${ }^{2,4,5}$, Irish Sea ${ }^{6}$ (marinus not then distinguished), English Channel $^{6}$ (marinus not then distinguished), France (Biscay) ${ }^{8}$, Spain ${ }^{9}$, Portugal $^{9}$, Mediterranean (Balearic Islands and Spanish coast from FrancoSpanish border to Cape Nao) ${ }^{9}$.

The records of tobianus to the south of the English Channel are included here since marinus has not yet been identified to the south of the Channel.

* Records to be published in a further communication.

$\dagger$ For explanation of figures see page 291 . 
Day (1880-84) records tobianus as common round the Irish coast. The preponderance of marinus to tobianus on the west coast of Scotland (Raitt, 1934) strongly suggests that marinus may occur on the Atlantic coast of Ireland.

G. semisquamatus. Norway ${ }^{13,14}$, Sweden ${ }^{15}$, North Sea ${ }^{5,16}$, Irish Sea ${ }^{12}$, western English Channel ${ }^{12,17}, 18$, France (Brittany) ${ }^{19}$, Spain (not coast of Galicia) ${ }^{9}$, Portugal ${ }^{9}$.

G. cicerellus. Mediterranean ${ }^{20}$, Black Sea ${ }^{20}$.

The distribution of the young stages of the European Ammodytidae cannot be so fully outlined as that of the adults owing to the fact that tobianus and marinus were not distinguished in the earlier accounts* before Kändler's (I94I) identification of the post-larva of marinus. Only those records, therefore, in which the possibility of confusion of these two species does not occur, are included in the following summary:

A. lanceolatus. Baltic ${ }^{4}$, north and west coasts of Scotland ${ }^{12}$, North Sea ${ }^{4}, 12$, Irish Sea ${ }^{21}$, Celtic Sea ${ }^{22}$, Plymouth ${ }^{22,23}$.

A. marinus. Faroes ${ }^{12}$, Baltic ${ }^{4}$, north and west coasts of Scotland ${ }^{12}$, North $\mathrm{Sea}^{12,20}$, Celtic Sea ${ }^{22}$, Plymouth ${ }^{22,23}$.

A. tobianus. Baltic ${ }^{4}$, north coast of Scotland ${ }^{12}$, North Sea ${ }^{12,20}$, Celtic Sea ${ }^{22}$, Plymouth 22, 23.

G. semisquamatus. Norway, Bergen (3 specimens, 47.5, 60.0 and $78.0 \mathrm{~mm}.)^{13}$; Channel Islands (2 specimens, 50.0 and $55^{\circ} 0 \mathrm{~mm}$.) + ; ? this species, Portugal, off River Tagus (4 specimens, 35.0-45.0 mm. $)^{24}$. Fage (I9I8) refers these specimens to the series of post-larvae of G. cicerellus from the Mediterranean although, as previously pointed out (p. 288, footnote), the locality of capture suggests, according to the distribution of the two species given by Duncker \& Mohr (1939), that they may be attributable to G. semisquamatus. This possibility is given support by the fact that a detailed comparison of the distribution of the individual melanophores which make up the gross pigmentation and of the gross pigmentation itself showed no differences between the specimens of semisquamatus found in the Channel Islands and examples of cicerellus of similar size from Sebastopol in the Black Sea (I2 specimens, 47.0-63.0 mm.) and also from the Naples area (2I specimens, $52 \cdot 0-68 \cdot 0 \mathrm{~mm}$.) $\neq$. There was, however, no difficulty in identifying the two species by their respective long (cicerellus) and short (semisquamatus) ventro-lateral skin fold (Duncker \& Mohr, 1939), and all

* See Appendix on pages 3II-I2.

† The writers are much indebted to Miss Ursula M. Grigg for the two specimens from the Channel Islands, which, as far as is known, are the only records of any young stages of G. semisquamatus from British waters. They were both found dead on the sand near low water (50 mm., Petit Port, Guernsey, 7 September I948; 55 mm., Beau Port, Jersey, 3I August 1948).

‡ The writers' thanks are due to Dr E. Trevawas, British Museum (Natural History), for permission to examine the Black Sea specimens, and to Dr R. Dohrn, Director of the Stazione Zoologica, for kindly providing the specimens from the Naples area. 
these juvenile specimens were referable to the genus Gymnammodytes by the characteristic structure of the lateral line (Jourdain, I879; Duncker \& Mohr, 1939). Concerning the four specimens taken off the mouth of the River Tagus, Fage wrote "Il est donc impossible de distinguer ces individus de ceaux à peine plus âgés (3 specimens, IO-I $2 \mathrm{~cm}$.) pris le 2I Février I9II à Messine...". And of the Mediterranean post-larvae of G. cicerellus, he observed that the striking melanophore pattern of the earlier stages (Figs. $5 \& 6 ; 7.5$ and II.0 mm.; Fage, I9I8) becomes less pronounced with increased size (Fig. $7 ; 25.0 \mathrm{~mm}$.; Fage, 1918). There is thus, in the late post-larvae and juveniles of these two species of Gymnammodytes, a similar difficulty of specific identification (by pigmentation alone) to that found in the same stages of the three species of Ammodytes (p. 294), although no such difficulty occurs in the earlier stages of the Ammodytes spp.

G. cicerellus. Western Mediterranean, Alboran Sea, Balearic Islands, Tyrrhenian Sea, Straits of Messina ${ }^{24}$; eastern Mediterranean, off Alexandria ${ }^{22}$; ? this species, Portugal, off River Tagus ${ }^{24}$ (see above).

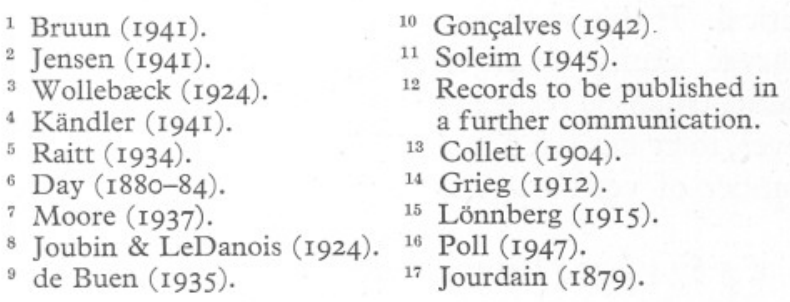

18 Moreau (I89r).

19 Acloque (I900).

20 Duncker \& Mohr (I939).

$21 \mathrm{Bal}$ (I944).

22 Present records.

23 Ford (I920).

24 Fage (r9r8).

\section{Problems IN IDENTifying the Post-Larvae}

The pigmentation of the $A$. lanceolatus and $A$. tobianus post-larvae in the present collections is in full agreement with the figures and descriptions given by Ford (1920), and the pigmentation of the A. marinus post-larvae agrees with Kändler's (I94I) figure and description. The pigmentation of the post-larva of G. cicerellus (Fage, I9I8, Figs. 5-7) is strikingly different from that of the above three species and from that of the species IV post-larva occurring in the Celtic Sea and Plymouth area. It has already been mentioned that the two post-larval forms of tobianus from the southern North Sea and Baltic are each distinguishable by a different pigmentation pattern (Kändler, I94I). The post-larvae of the spring brood (id., fig. $3 c$, p. 64) are more heavily pigmented in general than those of the autumn brood (id., p. 66), and Kändler (id., p. 65) identifies the darker spring form with the Plymouth tobianus post-larva described by Ford (1920). Ford's specimens were caught in late summer, July, August and September (Clark, 1920), and the tobianus post-larvae of the present collections also show a maximal occurrence in August and September (Table III, p. 304). 
As earlier remarked, the melanophore pattern of Kändler's more lightly pigmented autumn brood tobianus post-larva, of which he gives a full description, but unfortunately no figure, very closely resembles the pigmentation of the species IV post-larva which occurs in this area in the spring (Table III, p. 304).

It is important to emphasize the agreement of pigmentation in the lightly pigmented pair of post-larvae (species IV, this area; tobianus, North Sea and Baltic, Kändler) and in the dark pair (tobianus, this area, Ford; tobianus, North Sea and Baltic, Kändler), since the times of occurrence of each member of the two pairs are exactly opposite in the two areas:

\begin{tabular}{|c|c|c|c|c|}
\hline & Celtic S & nd Plymouth & Southern Nor & Sea and Baltic \\
\hline & Light forn & Dark form & Light form & Dark \\
\hline & $\begin{array}{c}\text { Species IV } \\
. .\end{array}$ & tobianus (Ford) & tobianus (Kändler) & $\begin{array}{c}\text { tobianus (Kändler) } \\
. .\end{array}$ \\
\hline
\end{tabular}

Notwithstanding this inversion in the times of occurrence, the two forms from each of the two areas might well be considered on the criterion of pigmentation to be identical. If this were so, a spring brood and an autumn brood of tobianus post-larvae, similar to the double brood found by Kändler in the North Sea and Baltic, could be recorded from Plymouth and the Celtic Sea. This appears, however, to be excluded by the following evidence obtained from a study of the number of vertebrae in the post-larvae (Table II and pp. 30I-4).

There is a separation of $5.67 \pm 0.400$ between the means of the number of vertebrae of the tobianus $(66.33 \pm 0.360)$ and species IV $(72.0 \pm 0.175)$ postlarvae from Plymouth and the Celtic Sea, and there is no overlap in their ranges (tobianus, 64-69: species IV, 70-74). A difference of this magnitude between the mean vertebral numbers of the two different Ammodytes postlarvae occurring in the same area, although at different seasons, is considered to preclude the possibility of their belonging to the same species.

Although Kändler has not examined the number of vertebrae in the postlarval tobianus of the spring and autumn broods from the southern North Sea and Baltic, his counts of adult spring and autumn spawners show only a very small difference of less than I 0 between their means (Kändler, I94I, Table 25, p. I22):

$\begin{array}{cc}\text { North Sea } & \text { Baltic } \\ 63.09 & 63.17 \\ 64.08 & 63.49 \\ 0.99 & 0.32 \\ \pm 0.071 & \pm 0.061\end{array}$

It is noteworthy that the means of the North Sea and Baltic autumnspawning adult tobianus ( 64.08 North Sea; 63.49 Baltic), which give rise to the autumn brood of post-larvae with the light pigmentation corresponding to species IV, are considerably lower than the mean of the tobianus post-larvae 
(66.33) from this area. The differences $(7.92,8.5 \mathrm{I})$ between the means of these North Sea and Baltic autumn-spawning adult tobianus and that of species IV are thus even greater than the difference $(5.67)$ between the means of species IV and the tobianus post-larva of this area. It is considered as before that these wide differences preclude the possibility of identifying the species IV postlarva with the tobianus post-larvae, in particular the light form, from the North Sea and Baltic.*

It has already been mentioned that the pigmentation of the post-larvae of G. cicerellus described by Fage (I9I8) is very distinct from that of the species IV post-larvae, and also that no post-larvae have hitherto been found which can be attributed to the adult $G$. semisquamatus, which occurs commonly in Scottish waters (Raitt, 1934). A sample of these Scottish G. semisquamatus $\dagger$ was found to have a mean vertebral number of $68 \cdot 16 \pm 0 \cdot 127$ (Table II, p. 302). This figure is $3.84 \pm 0.022$ less than the mean of species IV $(72 \cdot 0)$, and although it is the nearest approach to the species IV mean, it seems highly unlikely that an adult with a mean vertebral count of 68.16 could be related to a post-larva with a mean of $72 \cdot 0$, even allowing for geographical variation. $\ddagger$

It is therefore concluded from the above evidence that the post-larval Ammodytes species IV is not related to the Atlantic Gymnammodytes semisquamatus or to A. tobianus from either the Celtic Sea and Plymouth area or the southern North Sea and Baltic.

It appears then that the species IV post-larva cannot be attributed to a known adult, and it can only be concluded that it belongs to another species of Ammodytes. If this interpretation proves to be correct, the number of species of Ammodytidae in the Celtic Sea and Plymouth area is thus increased to five:
Adult:
A. lanceolatus
A. tobianus
G. semisquamatus
Not recorded Not known
Post-larva: A. lanceolatus
A. tobianus
Not recorded
A. marinus
Species IV

The description (pp. 299-500) and figures (Pl. II, fig, 2) of the species IV post-larva show that the type of development, the general body form and the scheme of pigmentation all very closely resemble the same characters in the post-larvae of lanceolatus, tobianus and marinus, and such conformity is held to substantiate the inclusion of species IV in the family Ammodytidae, although no certain distinction between the genera Ammodytes and Gymnammodytes can be made.

No great numbers of adult Ammodytidae have been collected and examined from this south-western area. With sufficient search it appears likely that adult

\footnotetext{
* Kändler's vertebral counts of adult tobianus from the North Sea and Baltic are here taken as representative of the vertebral counts of the post-larvae from the area.

† These specimens, part of Dr D. S. Raitt's original material, were kindly provided by Dr R. S. Clark, lately Director of the Marine Laboratory of the Scottish Home Department, Aberdeen.

\# There are no vertebral count data of Mediterranean $G$. cicerellus from which a mean can be calculated. Fage (I918) gives the range as 66-69 and Duncker \& Mohr (1939) give the figure $67(39+28)$. It is not stated whether these figures are inclusive or exclusive of the urostyle.
} 
marinus will be found. It remains to be seen whether further search will also bring to light the adult of species IV.

Despite the almost exclusive relation to post-larval stages of the present data, it is felt that they are worth publication in order that the numerous questions which call for further study may be brought to the notice of other workers. Some of the questions awaiting solution are at once apparent.

Vertebral count data of adult lanceolatus, marinus and species IV from this area are needed for comparison with the present post-larval data.

Further data are required to resolve the anomalous difference between the number of vertebrae in adult and post-larval tobianus from this area (p. 303).

A search for the adult of species IV must be made and, if successful, its identification will need to be established.

These problems arise directly from the present study. Others of wider relevance are also evident. Thus vertebral count data of both adult and post-larval G. cicerellus from the Mediterranean are required; while intimately connected with this is the need for continued search for the post-larva of the Atlantic G. semisquamatus, and for an investigation of the breeding habits of this species.

Of rather different character, but none the less important, is the need for full confirmation of the identification of the known Ammodytidae post-larvae with the known adults. A. lanceolatus appears to be the only species in which the post-larvae can with certainty be linked with the adult (pp. 30I-3). The available facts give every indication that the post-larvae of $A$. tobianus, $A$. marinus and the Mediterranean $G$. cicerellus are correctly assigned to their respective adults. It must, however, be admitted that the chain of evidence is not entirely complete. In none of these three species has it yet been possible fully to apply Schmidt's classic method of seriation from early larva to adult or recognizable adolescent. The frequently encountered difficulty of obtaining a full series of adolescent stages, intermediate between the late post-larva and the juvenile with adult characters, may be in part responsible for the gap. Moreover, in lanceolatus, tobianus and marinus, the specificity of the post-larval pigmentation lessens with increasing age until it is extremely difficult to separate the late post-larvae and early adolescents. Rearing from artificial fertilizations of known parentage should, however, provide material for comparison with the existing descriptions of the post-larvae of A. tobianus, A. marinus and G. cicerellus. But the difficulty of rearing a large enough number of young stages to a size suitable for alizarin staining presents considerable obstacles to the solution of the vertebral count problems. And were it achieved, it is certain that the laboratory conditions would greatly differ from the spawning ground conditions which are generally thought to have considerable influence on the definitive number of vertebrae. 


\section{MATERIAL}

The material for the present paper was collected by standard $\frac{1}{2} \mathrm{hr}$. oblique hauls of the $2 \mathrm{~m}$. stramin ring-trawl on the 1937-39 mackerel investigation cruises in the Celtic Sea (Corbin, 1947), and in the weekly plankton collections of 1930, I93I and 1935-37 taken near the Eddystone light-house for the purpose of observing the yearly fluctuations in the abundance of young fish in the Plymouth area (Russell, 1930-47). More than 6000 Ammodytes postlarvae from the 1937-39 cruises have been examined together with some 850 specimens from the Plymouth collections. They range in length from about $5 \mathrm{~mm}$. to about $30 \mathrm{~mm}$. The writers are much indebted to $\mathrm{Mr} \mathrm{F}$. S. Russell for the loan of the Plymouth young fish collections of 1930-37 and of specimens of G. cicerellus post-larvae from the Eastern Mediterranean off Alexandria, and to Mr G. M. Spooner for his help with the calculations. Further acknowledgements occur in the text.

\section{The Pigmentation of the Post-Larvae}

The nomenclature used to describe the pigmentation of the post-larvae is shown in Fig. I. An identification key is given on p. 300.

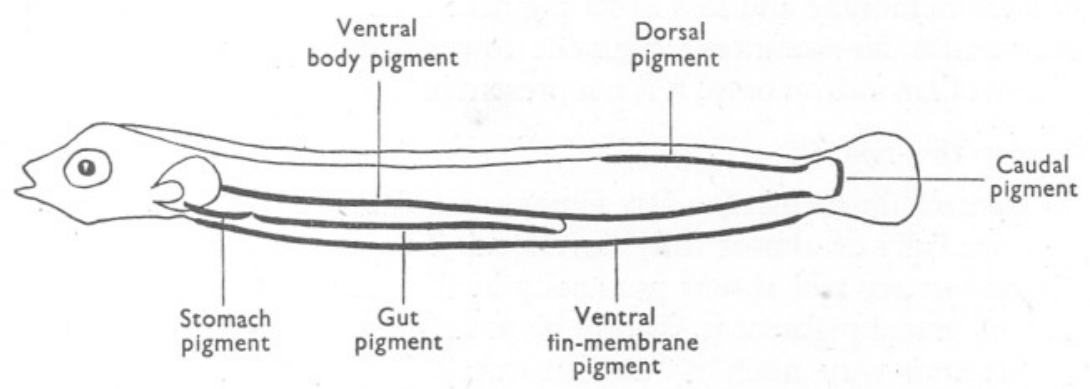

Text-fig. I. Diagram showing the nomenclature of the pigment rows.

\section{Ammodytes lanceolatus (Plate I, fig. I)}

Post-larva $4.5 \mathrm{~mm}$. (a)

The fin-membrane is entire from the head, round the body and tail to the throat. Ventral body pigment extends from behind the head to the tail; it is a double line of melanophores in the pre-anal region, a single line post-anally. The stomach pigment and gut pigment form a single row of melanophores, but are distinguishable by the closer spacing of the melanophores on the stomach. Ventral fin-membrane pigment is present as a row of melanophores extending from the stomach nearly to the tail. There is seldom any indication of a dorsal pigment row at this early stage. 


\section{Post-larva $7.5 \mathrm{~mm}$. (b)}

The fin-membrane is still complete. Ventral body pigment, stomach, gut and ventral fin-membrane pigment rows are as in the preceding stage. The first rudiments of caudal fin-rays show ventrally to the tip of the notochord, and caudal pigment is present as one or two melanophores at the base of the developing rays. The specimen illustrated has rather heavier caudal pigmentation than is usual at this stage. Dorsal pigment is represented by two or three melanophores in the immediate pre-caudal region. The specimen figured is in this respect also slightly more heavily pigmented than typically.

\section{Post-larva $12.5 \mathrm{~mm}$. (c)}

The dorsal and ventral fin-membranes are still complete, and dorsal and anal fin-rays are developing post-anally. Caudal fin-rays are well developed. Dorsal, caudal, ventral, stomach, gut and ventral fin-membrane pigmentation is similar to the preceding stage. Post-anally the ventral body pigment is a double row of melanophores almost to the tail. Teeth-like structures (Ford, 1920) are present on the upper jaw. It is of interest to compare this figure with the specimen illustrated by Ford (I920, Fig. I, p. 243) which, although very slightly smaller ( $12.0 \mathrm{~mm}$.), shows considerably more development of the dorsal, caudal and anal fin-rays, and almost complete disappearance of the ventral fin-membrane and loss of its pigment line.

The ventral fin-membrane pigment row is characteristic of the earlier post-larva of lanceolatus only; it is not present in marinus, tobianus or species IV.

\section{Post-larva $18.5 \mathrm{~mm} .(d)$}

The ventral fin-membrane has almost completely disappeared. The anal fin-rays are fully or almost fully developed. The dorsal fin-rays are further developed but are still absent pre-anally in the reduced fin-membrane. The dorsal and caudal pigment is slightly more developed. Pre-anally the ventral body pigment is very much less distinct than post-anally and is only visible by transparency through the abdominal walls. It becomes obscured by the thickening and downward growth of the walls of the abdomen. The stomach and gut pigment is much reduced at this stage or even absent. Teeth-like structures are present on the upper jaw.

\section{Post-larva $26.5 \mathrm{~mm}$. (e)}

Fin-rays are developed throughout the length of the dorsal fin. The dorsal pigment extends from the tail to just in front of the anus and is considerably more developed than in the preceding stage. The caudal pigment has increased. The pre-anal ventral body pigment is further obscured. The gut pigment is lost and the stomach pigment may be absent (as in the specimen figured) or represented by one to four small melanophores, seldom more. 


\section{Larva $6.25 \mathrm{~mm}$. (a)}

\section{Ammodytes marinus (Plate I, fig. 2)}

The fin-membrane is entire and an oil globule of considerable size is present. The earliest stages of lanceolatus, tobianus and species IV taken in the present collections are smaller than this larval marinus, but none has an oil globule. Dorsal pigment is absent. Ventral body pigment is present as a row of melanophores extending from behind the head to the end of the notochord. Pre-anally the row is double, post-anally it is single. The four or five terminal melanophores are not always as prominent as in the specimen illustrated. Stomach pigment is present. Gut pigment is lacking.

Post-larva $7.5 \mathrm{~mm}$. (b)

Pigmentation is similar to the preceding stage. The oil globule has been resorbed. The first indications of the developing caudal fin-rays are present.

\section{Post-larva II $\circ \mathrm{mm}$. (c)}

The dorsal pigment row is present as two or three melanophores. Considerable development of the caudal fin-rays is evident, and what will later be the caudal pigment row is clearly seen at the base of the caudal rays. Other pigmentation resembles the preceding stage.

\section{Post-larva $14.0 \mathrm{~mm}$. (d)}

Dorsal and ventral fin-rays are starting to develop in the post-anal region. The caudal pigment forms a prominent line of melanophores at the base of the caudal fin-rays which are now well developed. A slight increase in the number of melanophores in the dorsal pigment row is usual at this stage, although not apparent in the specimen figured. The gut pigment develops at this stage or a little earlier; it shows considerable variation. It may consist of a well-marked regular line of melanophores from stomach to anus, it may be completely lacking, or it may be an incomplete and interrupted row (see below, post-larvae of 18.5 and $19.0 \mathrm{~mm}$.).

\section{Post-larva $18.5 \mathrm{~mm}$. (e)}

The dorsal and anal fin-rays are almost fully developed in the post-anal region. Fin-ray development is not yet complete in the pre-anal region where the dorsal fin-membrane is reduced. The dorsal pigment is slightly increased and some gut pigment is present.

\section{Post-larva I9.0 $\mathrm{mm} .(\mathrm{f})$}

This specimen which is at the same developmental stage as the above specimen of $18.5 \mathrm{~mm}$., has generally heavier pigmentation, particularly in the dorsal row and on the gut. 


\section{Post-larvae 23.0 and $27.5 \mathrm{~mm}$. ( $g$ and $h$ )}

A forward extension of the dorsal pigment is seen in these specimens. Other pigmentation remains essentially the same. Fin-ray development in the dorsal fin is complete.

From about Io mm. onwards, the pre-anal ventral body pigment of marinus is very prominent. Although situated on the inner side of the walls of the abdomen, it remains markedly conspicuous and is not obscured by the increasing thickening of the developing abdomen wall until a much later stage than in lanceolatus, tobianus and species IV.

\section{Ammodytes tobianus (Plate II, fig. I)}

\section{Post-larva $5.25 \mathrm{~mm}$. (a)}

The fin-membrane is entire. The dorsal pigment consists of two melanophores situated a short distance forward of the tip of the notochord. The ventral body pigment extends from behind the head to a point just short of the tip of the notochord. Stomach pigment consists of a closely spaced row of melanophores which under certain conditions of expansion give the appearance of an almost continuous line. The gut pigment line continues on from the stomach pigment to the anus, but the melanophores are more openly spaced than in the stomach pigment line.

Post-larva $8.0 \mathrm{~mm}$. (b)

The dorsal pigment row has developed considerably since the preceding stage. There is a small pre-anal group of melanophores and a fairly welldeveloped row post-anally. This interrupted appearance of the dorsal row, before the development of an unbroken line, is very characteristic of the earlier post-larvae of tobianus. Kändler (I94I) makes this observation. Caudal fin-rays have begun to develop, but no dorsal or anal rays yet.

\section{Post-larva $8.75 \mathrm{~mm}$. (c)}

Dorsal and anal fin-rays have begun to develop in the post-anal region. The caudal fin rays are well developed. The dorsal pigment line has increased since the preceding stage; it extends the full length of the body from the nape of the neck to the tail. It is more pronounced in the post-anal half; the melanophores are regularly spaced and larger than those in the pre-anal region where the spacing is somewhat uneven. The pre-anal ventral body pigment is less prominent than the post-anal section owing to the opacity of the abdomen walls. The contrast between the close spacing of the stomach pigment and the open spacing of the gut pigment is more evident here than in the earlier stage. No caudal pigment is present.

\section{Post-larva II $\cdot 0 \mathrm{~mm}$. (d)}

Pigmentation is very similar to the preceding stage. Fin-ray development is further advanced. 
Post-larva $15.5 \mathrm{~mm}$. (e)

Fin-ray development in the dorsal fin is complete. For comparison it may be recalled that no pre-anal dorsal fin-rays are present in lanceolatus and marinus post-larvae of 18 or $19 \mathrm{~mm}$. Ford (1920) observed this earlier development in tobianus. The dorsal pigment is complete from the neck to the tail, but is still more prominent in the posterior half. Two caudal melanophores are present. The gut pigment line is slightly broken.

Post-larva $23.0 \mathrm{~mm}$. $(f)$

Caudal pigmentation is considerably increased. A medio-lateral line has begun to develop posteriorly. The pre-anal ventral body pigment is entirely obscured by thickening of the abdominal wall. The gut pigment line is further broken and reduced, but the stomach pigment is still prominent and characteristically closely spaced.

\section{Ammodytes species IV (Plate II, fig. 2)}

Post-larva $5.5 \mathrm{~mm}$. (a)

The fin-membrane is entire. Dorsal pigment is represented by three melanophores in the pre-caudal region. Ventral body pigment extends from the region of the stomach to the tail, but not to the extremity of the notochord. Stomach pigment is present, but no gut pigment.

Post-larva $9.0 \mathrm{~mm}$. (b)

Considerable caudal fin-ray development is evident. The dorsal pigment line now extends from the position of the anus to the root of the tail. No caudal pigment is present.

Post-larva $13.0 \mathrm{~mm}$. (c)

Dorsal and anal fin-rays are beginning to develop in the post-anal region of the fin-membranes, and caudal fin-ray development is further advanced. Pigmentation is similar to that of the preceding stage. The dorsal and post-anal ventral body pigmentation is more pronounced.

Post-larva $\mathrm{I} 7.5 \mathrm{~mm} .(d)$

Caudal and anal fin-ray development is complete. Dorsal fin-rays are starting to develop pre-anally. A slight forward increment of the dorsal pigment is evident. A single melanophore is present at the base of the caudal fin-rays. The pre-anal ventral body pigment is becoming obscured by the thickening of the abdominal walls.

Post-larva 26.0 mm. (e)

Dorsal fin-ray development is complete. The dorsal pigment row has extended forward to the neck region, but post-anally it is more prominent. 
Caudal pigmentation is now fairly pronounced. A medio-lateral pigment line is present in the pre-caudal region.

The foregoing descriptions of the pigmentation of lanceolatus, tobianus, marinus and species IV post-larvae have been confined to the longitudinal pigment rows shown in the diagram in Text-fig. I. Another pigmentation feature common to marinus, tobianus and species IV, but not found in lanceolatus, is the presence of a melanophore at the base of each pectoral fin. This pair of pectoral melanophores is present in the post-larvae of marinus and species IV from a length of about IO-I2 $\mathrm{mm}$. onwards. In tobianus it is generally present earlier, from a length of about 7-8 $\mathrm{mm}$.

Certain additional differences both of pigmentation and form are also to be noted. Ehrenbaum (1904) observed that the length of the upper jaw in relation to the diameter of the eye is greater in lanceolatus than in tobianus. Ford's (I920, Table II, p. 245) detailed measurements of these features show that this difference is apparent at all observed lengths but becomes particularly marked above a length of 8-10 $\mathrm{mm}$. It was immediately noticeable in the mixed hauls of the present collections that the snout of the lanceolatus post-larvae is relatively longer than that of marinus and species IV as well as that of tobianus. Ford (1920) also noted that tobianus post-larvae are more advanced in structural development than lanceolatus post-larvae of the same length, and, it may now be added, than marinus and species IV post-larvae. The earlier development of the pectoral melanophores referred to above and the earlier replacement of cartilage by bone (p. 30I) in tobianus post-larvae is in agreement with this observation. It should be further noted that the differences in the caudal pigmentation of the early and middle post-larvae of the four species described are lost in the late post-larval stage when the development of fin-rays is complete in the dorsal fin. The caudal pigment is then present in each of the four species as a row of melanophores at the base of the caudal fin-rays (Pl. I, fig. $1 e$, fig. $2 h$; Pl. II, fig. I $f$, fig. $2 e$ ).

\section{Identification key to the Ammodytes post-larvae of the Celtic Sea and Plymouth area}

I (2) Ventral fin-membrane pigment row present. Pectoral melanophores absent. Teeth-like structures on upper jaw present. Vomerine teeth present.

A. lanceolatus

2 (I) Ventral fin-membrane pigment row absent. Pectoral melanophores present. Teeth-like structures on upper jaw absent. Vomerine teeth absent.

3 (4) Caudal pigment strongly marked from earliest post-larval stage; not always present in earliest larvae with large oil-globule.

A. marinus

4 (3) Caudal pigment absent or very reduced until late post-larval stages.

5 (6) Ventral gut pigment present.

A. tobianus

6 (5) Ventral gut pigment absent.

A. species $I V$ 


\section{The Number of Vertebrae in the Post-Larvae and Adults}

The number of vertebrae was counted in alizarin-stained post-larvae of lanceolatus, marinus, tobianus and species IV. These data are given in Table I, together with a count of the number of vertebrae in a sample of adult tobianus from Exmouth (September 1947) ${ }^{\star}$. Counts were made only from those specimens in which staining revealed that bone had fully replaced cartilage. This takes place in tobianus post-larvae at a length of about $13 \mathrm{~mm}$., whereas lanceolatus, marinus and species IV post-larvae will not successfully stain below a length of $18-19 \mathrm{~mm}$. This difference is in agreement with the previously noted earlier development of tobianus post-larvae.

Table I. The Number of Vertebrae in the Post-Larval Ammodytes spp. of the Celtic Sea and Plymouth Area

\begin{tabular}{|c|c|c|c|c|c|}
\hline \multirow{3}{*}{$\begin{array}{c}\text { No. of } \\
\text { vertebrae } \\
\text { (including } \\
\text { urostyle) }\end{array}$} & \multicolumn{5}{|c|}{ Number of specimens } \\
\hline & \multicolumn{2}{|c|}{ A. tobianus } & \multirow[b]{2}{*}{$\begin{array}{l}\text { A. lanceolatus } \\
\text { (post-larvae) }\end{array}$} & \multirow[b]{2}{*}{$\begin{array}{c}\text { A. marinus } \\
\text { (post-larvae) }\end{array}$} & \multirow[b]{2}{*}{$\begin{array}{l}\text { Ammodytes } \\
\text { species IV } \\
\text { (post-larvae) }\end{array}$} \\
\hline & Post-larvae & $\begin{array}{c}\text { Adults } \\
\text { (Exmouth) }\end{array}$ & & & \\
\hline 62 & . & I & . & ... & . \\
\hline 63 & $\ldots$ & I2 & $\ldots$ & $\ldots$ & $\ldots$ \\
\hline 64 & I & 23 & I & $\ldots$ & $\ldots$ \\
\hline 65 & I & IO & . & $\ldots$ & $\ldots$ \\
\hline $\begin{array}{l}66 \\
67\end{array}$ & 6 & 6 & I & $\ldots$ & .. \\
\hline $\begin{array}{l}67 \\
68\end{array}$ & 2 & $\ldots$ & 9 & 5 & $\ldots$ \\
\hline $\begin{array}{l}68 \\
69\end{array}$ & I & $\ldots$ & 24 & 16 & . \\
\hline $\begin{array}{l}69 \\
70\end{array}$ & I & $\ldots$ & 15 & I8 & $\ldots$ \\
\hline 70 & $\ldots$ & $\ldots$ & 2 & 6 & 2 \\
\hline $\begin{array}{l}71 \\
72\end{array}$ & $\ldots$ & $\ldots$ & . & $\ldots$ & 4 \\
\hline $\begin{array}{l}72 \\
73\end{array}$ & $\ldots$ & $\ldots$ & $\ldots$ & $\ldots$ & I6 \\
\hline $\begin{array}{l}73 \\
74\end{array}$ & $\ldots$ & $\ldots$ & $\ldots$ & $\ldots$ & 4 \\
\hline $\begin{array}{c}74 \\
\text { Total no of }\end{array}$ & $\cdots$ & $\ldots$ & . & $\ldots$ & 2 \\
\hline $\begin{array}{l}\text { Total no. of } \\
\text { specimens }\end{array}$ & 12 & 52 & 52 & 45 & 28 \\
\hline $\begin{array}{l}\text { Mean verte- } \\
\text { bral no. }\end{array}$ & $66 \cdot 33$ & $64 \cdot 15$ & $68 \cdot 08$ & $68 \cdot 56$ & $72 \cdot 00$ \\
\hline $\begin{array}{l}\text { Standard error } \\
\text { of mean }\end{array}$ & \pm 0.360 & \pm 0.134 & \pm 0.082 & \pm 0.128 & \pm 0.175 \\
\hline$\sigma$ & $\mathrm{I} \cdot 247$ & 0.969 & 0.997 & 0.857 & 0.926 \\
\hline
\end{tabular}

Alizarin staining of post-larval lanceolatus clearly showed the denticles on the upper jaw, a specific recognition character of the post-larva (Ford, 1920), and also made visible the pair of teeth on the vomer. It is of some importance to draw attention to the vomerine teeth in the post-larva of lanceolatus. They are a primary specific character of the adult. But as far as is known, there is no reference in the literature to their presence in the post-larva, which thus establishes a complete chain of specific characters in the development of lanceolatus from the late larva to the adult. The ventral fin-membrane pigment

* The writers are indebted to $\mathrm{Mr} \mathrm{N}$. A. Holme for kindly obtaining these specimens. 


\section{TAble II. The Number of Vertebrae In the North AtLantic Species of Ammodytidae}

The standard deviation $(\sigma)$ and the standard error of the mean have been calculated from the data of the authors quoted, with the exception of Kändler (194I), who gives values for the latter.

\begin{tabular}{|c|c|c|c|c|c|c|c|}
\hline & & Author & $\begin{array}{l}\text { No. of } \\
\text { specimens v }\end{array}$ & $\begin{array}{l}\text { Mean } \\
\text { no. of } \\
\text { vertebrae }\end{array}$ & $\begin{array}{l}\text { Standard } \\
\text { error of } \\
\text { mean }\end{array}$ & $\begin{array}{c}\text { Range of } \\
\text { no. of } \\
\text { vertebrae }\end{array}$ & $\sigma$ \\
\hline & & A. tobian & & & & & \\
\hline Iceland & & Bruun (I94I) & 52 & $62 \cdot 56$ & \pm 0.125 & $00-05$ & 0.902 \\
\hline aroes & & Bruu & 22 & & \pm 0.200 & & 0.940 \\
\hline Baltic, spring & spawners & & $96 \mathrm{I}$ & $63 \cdot 17$ & \pm 0.033 & $60-67$ & I.035 \\
\hline autum & n spawners & Kändler (I94I, & 566 & 63.49 & \pm 0.051 & $60-67$ & $\begin{array}{l}I \cdot 216 \\
0.044\end{array}$ \\
\hline $\begin{array}{l}\text { North Sea, spri } \\
\text { autı }\end{array}$ & 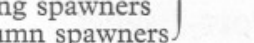 & & $\begin{array}{l}274 \\
566\end{array}$ & $\begin{array}{l}63.09 \\
64.08\end{array}$ & $\begin{array}{l} \pm 0.057 \\
+0.043\end{array}$ & $\begin{array}{l}6 I-65 \\
6 I-68\end{array}$ & $\begin{array}{l}0.944 \\
I \cdot 03 I\end{array}$ \\
\hline $\begin{array}{l}\text { Northern Nortl } \\
\text { Denmark } \\
\text { Exmouth }\end{array}$ & Sea & $\begin{array}{l}\text { Raitt (1934) } \\
\text { Jensen (I94I) } \\
\text { Present records }\end{array}$ & $\begin{array}{r}199 \\
82 \\
52\end{array}$ & $\begin{array}{l}63 \cdot 37 \\
63 \cdot 37 \\
64 \cdot 15\end{array}$ & $\begin{array}{l} \pm 0.063 \\
\pm 0.108 \\
\pm 0.134\end{array}$ & $\begin{array}{l}60-66 \\
61-65 \\
62-66\end{array}$ & $\begin{array}{l}0.984 \\
0.982 \\
0.969\end{array}$ \\
\hline Plymouth, post- & larvae & Present records & I2 & $66 \cdot 33$ & \pm 0.360 & $64-69$ & I.247 \\
\hline & & A. lanceol & tus & & & & \\
\hline $\begin{array}{l}\text { Baltic } \\
\text { North Sea }\end{array}$ & & $\begin{array}{l}\text { Kändler (I94I, } \\
\text { table } 23, \text { p. I20) }\end{array}$ & $\begin{array}{l}126 \\
293\end{array}$ & $\begin{array}{l}66 \cdot 73 \\
66 \cdot 85\end{array}$ & $\begin{array}{l} \pm 0.076 \\
\pm 0.047\end{array}$ & $\begin{array}{l}65-69 \\
65-69\end{array}$ & $\begin{array}{l}0.853 \\
0.805\end{array}$ \\
\hline Celtic Sea, post & -larvae & Present records & 52 & 68.08 & \pm 0.082 & $64-70$ & 0.997 \\
\hline & & A. marin & & & & & \\
\hline Greenland & & Jensen (I94I) & 38 & $69 \cdot 39$ & \pm 0.195 & $67-72$ & $I \cdot 204$ \\
\hline Iceland & & Bruun (I94I) & 97 & 71 & \pm 0 & $68-73$ & I. 104 \\
\hline Iceland & & $\begin{array}{l}\text { Kändler (I94I, } \\
\text { table 24, p. I20) }\end{array}$ & 31 & $7 \mathrm{I} \cdot 13$ & \pm 0.217 & $69-73$ & I.208 \\
\hline & (Grense Jakobslev) & & 200 & $7 \mathrm{I} \cdot 74$ & \pm 0.088 & $69-75$ & I. 243 \\
\hline North Norway & $\begin{array}{l}\text { Grense Jakobslev } \\
\text { 30 Oct. I939 }\end{array}$ & Soleim (I945) & I68 (I70) & $72 \cdot 06$ & \pm 0.088 & $69-74$ & $\mathrm{I} \cdot \mathrm{I} 45$ \\
\hline & 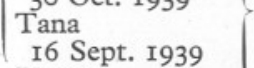 & & 89 & $7 I \cdot 88$ & \pm 0.119 & $69-74$ & $I \cdot I 20$ \\
\hline South Norway & $\begin{array}{l}\text { Bergen } \\
2 \text { Sept. I94I }\end{array}$ & & 200 & $69 \cdot 53$ & \pm 0.076 & $67-72$ & I.074 \\
\hline $\begin{array}{l}\text { Faroes } \\
\text { Northern Nortl } \\
\text { North Sea, Ger } \\
\text { Central Baltic, } \\
\text { East Baltic, Eas }\end{array}$ & $\left.\begin{array}{l}\text { Sea } \\
\text { man Bight } \\
\text { Pomerania } \\
\text { t Prussia }\end{array}\right\}$ & $\begin{array}{l}\text { Bruun (I94I) } \\
\text { Raitt (I934) } \\
\text { Kändler (I94I, } \\
\text { table 24, p. I20) }\end{array}$ & $\begin{array}{r}129 \\
205 \\
67 \\
114 \\
29 I^{\star}\end{array}$ & $\begin{array}{l}69 \cdot 67 \\
69 \cdot 21 \\
69 \cdot 75 \\
68 \cdot 90 \\
68 \cdot 50\end{array}$ & $\begin{array}{l} \pm 0.084 \\
\pm 0.079 \\
\pm 0.124 \\
\pm 0.107 \\
\pm 0.066\end{array}$ & $\begin{array}{l}68-72 \\
67-72 \\
67-72 \\
66-72 \\
65-72\end{array}$ & $\begin{array}{l}0.950 \\
1 \cdot 131 \\
1 \cdot 015 \\
1 \cdot 142 \\
1 \cdot 135\end{array}$ \\
\hline Celtic Sea, post & -larvae & Present records & 45 & $68 \cdot 56$ & \pm 0.128 & $67-70$ & 0.858 \\
\hline & & Ammod & es IV & & & & \\
\hline Celtic Sea, post & -larvae & Present records & 28 & $72 \cdot 00$ & \pm 0.175 & $70-74$ & 0.926 \\
\hline & & G. sen & tus & & & & \\
\hline West Scotland & and northern & Present records & $5 \mathrm{I}$ & $68 \cdot 16$ & \pm 0.127 & $65-70$ & 0.901 \\
\hline & & A. dul & & & & & \\
\hline $\begin{array}{l}\text { West Greenlan } \\
\text { West Greenlan }\end{array}$ & & $\begin{array}{l}\text { Jensen (I94I) } \\
\text { Jensen (I944, } \\
\text { p. I5, note 5). }\end{array}$ & $\begin{array}{r}179 \\
53\end{array}$ & $\begin{array}{l}75 \cdot 10 \\
75 \cdot 07\end{array}$ & \pm 0.082 & $\begin{array}{r}73-78 \\
?-80\end{array}$ & I.099 \\
\hline
\end{tabular}

* This figure is given, evidently in error, as I $9 \mathrm{r}$ in Kändler's paper. 
row (p. 296) still persists when the denticles on the upper jaw appear (Pl. I, fig. I c), and these in turn are still present when the adult character of the vomerine teeth appears in the later post-larvae.

For comparison with the vetebral counts of the post-larvae of this area (Table I), data obtained by other investigators from other north Atlantic areas are given in Table II.

\section{Ammodytes tobianus}

The number of tobianus post-larvae of stainable size was unfortunately small. There is, nevertheless, a significant difference between the mean number of vertebrae of the Plymouth post-larvae and of the adults from Exmouth and elsewhere. The excess, 2.18, of the Plymouth post-larvae over the Exmouth adults is more than five times its error: in fact the two populations appear to differ by at least $\mathrm{r} \cdot 40$. Until further data from this area are obtainable on the number of vertebrae in both the adults and post-larvae, this difference will remain something of an anomaly. The mean of the Exmouth sample is in keeping with the findings of other authors. But the mean of the post-larvae suggests, despite the smallness of the sample, that what are here taken to be tobianus do not in fact belong to the species. On the other hand, the pigmentation and time of occurrence of the post-larvae are characteristic of tobianus. The pigmentation of each individual was very carefully noted before staining and without exception was in full agreement with the figures and descriptions of Ford (I920) and Kändler (I94I) (dark form, spring brood).

\section{Ammodytes lanceolatus}

Kändler's figures (I94I, Table 23, p. I20) are the only published data from large samples on the number of vertebrae in adult lanceolatus. Their means are noticeably lower than the mean of the Celtic Sea post-larvae. As mentioned above, the identification of the post-larvae was confirmed by the denticles on the upper jaw and the pair of vomerine teeth.

\section{Ammodytes marinus}

The data for this species show the very considerable range of the mean number of vertebrae.

Mr P. A. Soleim informed us that his original data were not available; they were unfortunately lost during the course of post-war changes. The data in Table II relating to his samples of marinus were therefore calculated from careful measurements (in hundredths of an inch) of his published graphs (Soleim, I945: fig. 7, p. I3 and fig. Io, p. I6). From the given total of specimens in each sample, the number at each different vertebral count was calculated, and hence the mean, standard deviation $(\sigma)$ and standard error of the mean for each sample. In the Grense Jakobslev sample of 30 October I939, the total number of specimens calculated from measurement is I68 instead of 170 as given by Soleim. This small discrepancy is unlikely to make any great difference in the ensuing calculations. In the other three samples, the totals calculated from measurement agree with those given by Soleim. 


\section{Ammodytes species IV}

The nearest approach to the mean number of vertebrae of this post-larva occurs in adult marinus from northern Norway (Soleim's samples from Grense Jakobslev and Tana).

Data for G. semisquamatus and A. dubius are included for comparison with the foregoing species.

\section{Table III. The Seasonal Occurrence of Post-Larval Ammodytes spp. in Plymouth Waters IN I930-3I AND I935-37}

Owing to loss and damage of some specimens, the monthly totals do not always agree with Mr F. S. Russell's original figures. The discrepancies are, however, not sufficient to distort the general results.

Monthly averages for the five years are shown in parentheses. The number of hauls per month are given under $A$. lanceolatus against the total of specimens taken in the month.

* denotes months in which a species occurred on the 1937-39 cruises.

\begin{tabular}{|c|c|c|c|c|c|c|c|c|c|c|}
\hline & \multicolumn{5}{|c|}{ A. lanceolatus } & \multicolumn{5}{|c|}{ A. marinus } \\
\hline & 1930 & 31 & 35 & 36 & 37 & I930 & $3 I$ & 35 & 36 & 37 \\
\hline Jan. & &.$^{6}$ &.$^{6}$ & $\cdots^{5}$ &.$^{4}$ & & $\cdots$ & $\cdots$ & 4 & $\ldots(0.2)$ \\
\hline Feb. & $\cdots^{4}$ & $\ldots^{4}$ & $\mathrm{I}^{3}$ &.$^{3}$ & $4^{4}(0.3)$ & $\cdots$ & . & $\ldots$ & 18 & $\ldots(\mathrm{I} \cdot 2)$ \\
\hline Mar. & $\cdots_{5}^{4}$ & $2^{2}$ & $5_{86}^{3}$ & $4^{4}$ & $30^{5}(1 \cdot 9)$ & 2 & $3 I$ & $2 \mathrm{I}$ & 6 & $4\left(5^{\prime} \mathrm{I}\right)_{\star}$ \\
\hline Apr. & $\cdots^{5}$ & $\mathrm{I}^{5}$ & $8^{6}$ & $19^{4}$ & I2 ${ }^{4}(\mathrm{I} \cdot 86)^{\star}$ & . & $\cdots$ & $\cdots$ & $\cdots$ & $\cdots$ \\
\hline May & $4^{3}$ & $2^{4}$ & $16^{7}$ & $4^{4}$ & $2 \mathrm{I}^{5}(\mathrm{I} \cdot 86)^{\star}$ & $\cdots$ & $\cdots$ & $\cdots$ & $\cdots$ & $\cdots$ \\
\hline June & $4^{3}$ & $\mathrm{II}^{3}$ & $4^{2}$ & $10^{4}$ & $5^{3}(2 \cdot 2)$ & $\cdots$ & $\cdots$ & $\cdots$ & $\cdots$ & $\cdots$ \\
\hline $\begin{array}{l}\text { July } \\
\text { Aug }\end{array}$ & $\begin{array}{l}17^{5} \\
52^{4}\end{array}$ & I5 & $6^{6}$ & $14^{4}$ & $4^{4}(2 \cdot 5)$ & $\cdots$ & $\cdots$ & $\cdots$ & $\cdots$ & $\cdots$ \\
\hline $\begin{array}{l}\text { Aug. } \\
\text { Sept. }\end{array}$ & $\begin{array}{r}53^{4} \\
I^{4}\end{array}$ & $\begin{array}{l}5^{4} \\
3^{4}\end{array}$ & $5^{5}$ & $4_{5}^{*}$ & $3_{5}^{4}(3.5)$ & $\because$ & $\cdots$ & $\cdots$ & $\cdots$ & $\cdots$ \\
\hline Oct. & $\ldots^{4}$ & $.3^{5}$ & $\ldots^{5}$ & $\mathrm{I}^{2}$ &.$^{4}(0 . \mathrm{I})$ & $\because$ & $\cdots$ & $\because$ & $\cdots$ & $\cdots$ \\
\hline Nov. & $\ldots^{4}$ & $\ldots^{1}$ &.$^{2}$ & & $\ldots^{4}$ & .. & $\cdots$ & $\ldots$ & $\cdots$ & $\ldots$ \\
\hline \multirow[t]{3}{*}{ Dec. } & $\cdots^{4}$ & $\cdots^{5}$ &.$^{3}$ &.$^{3}$ &.$^{4}$ & . & . & . & $\cdots$ & $\cdots$ \\
\hline & \multicolumn{5}{|c|}{ A. tobianus } & \multicolumn{5}{|c|}{ Ammodytes species IV } \\
\hline & I930 & $3 I$ & 35 & 36 & 37 & I930 & $3 I$ & 35 & 36 & 37 \\
\hline Jan. & & $\cdots$ & . & $\cdots$ & . & & $\because$ & 3 & 28 & $85(5 \cdot 0)$ \\
\hline Feb. & $\cdots$ & $\cdots$ & $\cdots$ & $\cdots$ & $\cdots$ & $\cdots$ & 5 & I7 & 26 & $86(5 \cdot 4)$ \\
\hline Mar. & $\cdots$ & $\cdots$ & $\cdots$ & $\cdots$ & $\cdots$ & 9 & 35 & 53 & 13 & $37(7 \cdot 4)$ \\
\hline Apr. & $\cdots$ & $\because$ & $\cdots$ & $\cdots$ & . & I & 3 & 9 & 5 & $6(\mathrm{I} \cdot \mathrm{O})^{\star}$ \\
\hline May & $\cdots$ & I & $\cdots$ & $\cdots$ & $\ldots(0.05)$ & I & $\cdots$ & $\cdots$ & $\cdots$ & $\ldots(0.07)$ \\
\hline June & $\cdots$ & I & $\cdots$ & $\cdots$ & $\ldots(0.07)$ & $\cdots$ & $\cdots$ & $\cdots$ & * & $\cdots$ \\
\hline July & $\cdots$ & I & . & $\because$ & $2(0.2)$ & $\cdots$ & $\cdots$ & $\cdots$ & $\cdots$ & . \\
\hline Aug. & I & $\cdots$ & $\because$ & I0 & $\cdots(0.6)$ & $\cdots$ & $\cdots$ & $\cdots$ & $\cdots$ & $\cdots$ \\
\hline Sept. & $\cdots$ & I & 8 & 3 & $\ldots(0.5)$ & $\cdots$ & $\cdots$ & $\cdots$ & $\cdots$ & $\cdots$ \\
\hline Oct. & $\cdots$ & I & 5 & $\cdots$ & $\ldots(0.2)$ & $\cdots$ & $\cdots$ & $\cdots$ & $\cdots$ & $\cdots$ \\
\hline Nov. & $\cdots$ & $\cdots$ & $\cdots$ & & $\cdots$ & $\cdots$ & $\cdots$ & $\cdots$ & & $2(0.10)$ \\
\hline Dec. & $\cdots$ & $\cdots$ & $\cdots$ & $\cdots$ & . & $\cdots$ & . & $\cdots$ & $\cdots$ & $\cdots$ \\
\hline
\end{tabular}

The March and August averages of $A$. lanceolatus are high owing to single large catches of twenty-seven and forty-seven specimens on I March 1937 and 7 August I930 respectively. The January average of Ammodytes species IV is similarly weighted by a catch of eighty-two specimens on 27 January 1937.

\section{The Seasonal Occurrence and Distribution of the Post-Larvae}

The seasonal occurrence of the four species of Ammodytes post-larvae in the Plymouth area in the years 1930, I93I and 1935-37, together with the occurrences on the 1937-39 cruises in the Celtic Sea, is shown in Table III. It is evident that $A$. lanceolatus has a long spawning period lasting from early spring 

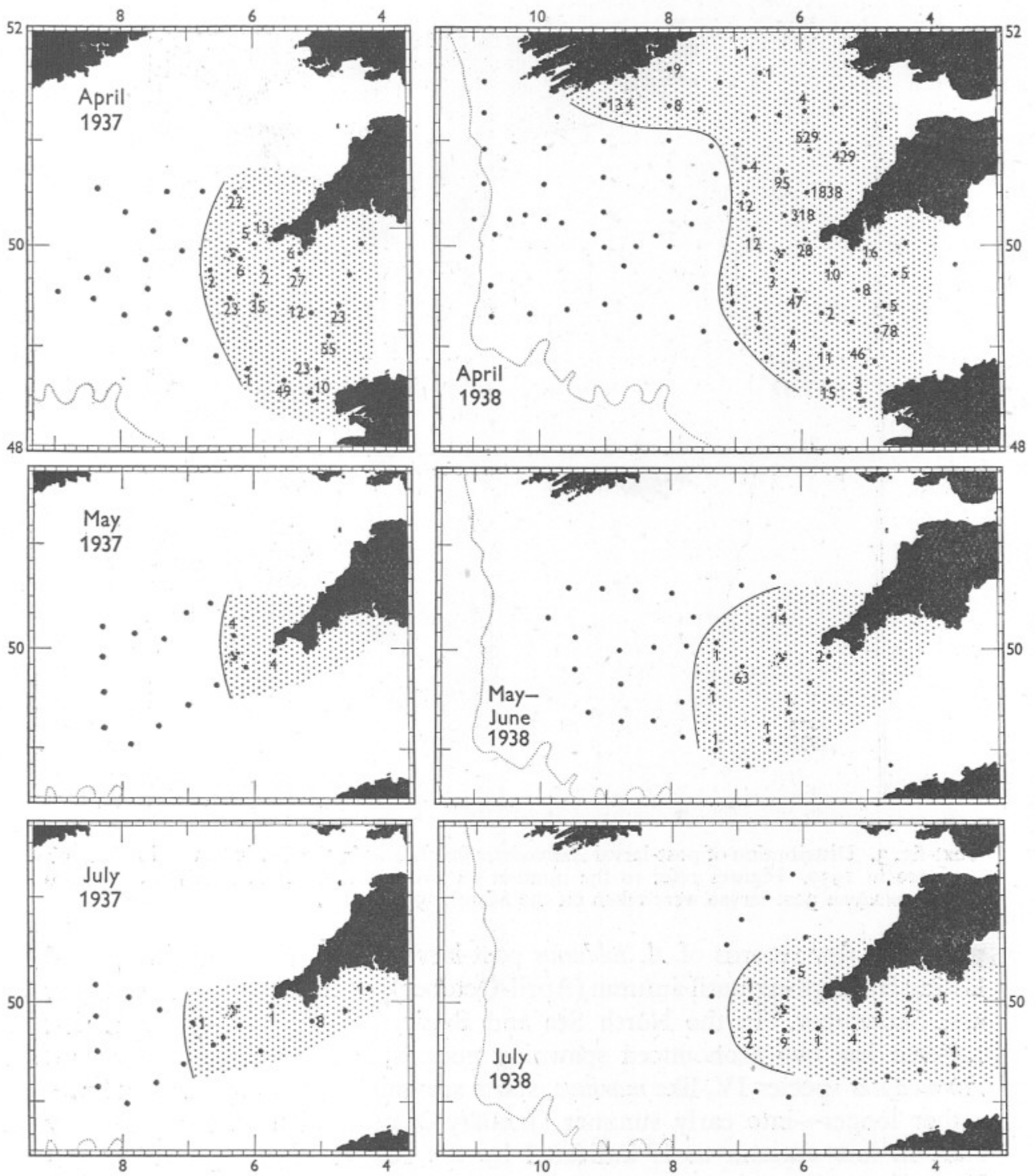

Text-fig. 2. Distribution of post-larval Ammodytes lanceolatus in the Celtic Sea and Plymouth area in 1937 and 1938. Figures refer to the number of post-larvae caught at each station. The dotted line in this and succeeding figures indicates the roo-fathom contour.

until autumn (February-October) with a maximum in mid-summer. A.marinus spawns in winter and early spring (January-April). The spawning times of these two species are in agreement with Raitt's observations for Scottish waters (1934) and Kändler's for the North Sea and Baltic (194I). The com- 

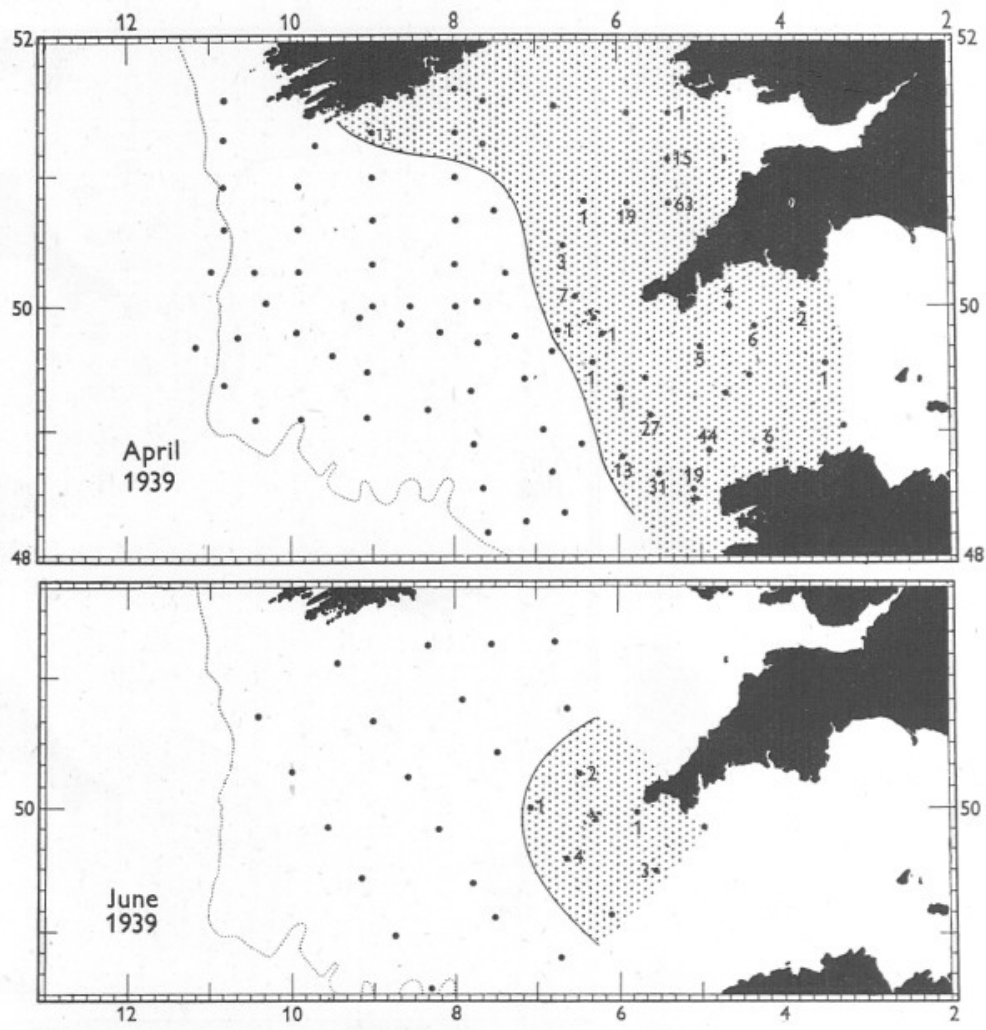

Text-fig. 3. Distribution of post-larval Ammodytes lanceolatus in the Celtic Sea and Plymouth area in 1939. Figures refer to the number of post-larvae caught at each station. No Ammodytes post-larvae were taken on the March 1939 cruise.

paratively few records of $A$. tobianus post-larvae point to a spawning period lasting from spring until autumn (April-October), with a maximum in August and September. In the North Sea and Baltic, Kändler (I94I) found that tobianus has two pronounced spawning periods, in spring and in autumn. Ammodytes species IV, like marinus, starts spawning in winter, but continues rather longer-into early summer (January-May), and it may occasionally start in late autumn as is indicated by the record of two post-larvae in November 1937.

The numbers and distribution of the post-larvae taken on the I937-39 cruises are shown in Text-figs. 2-6. For details of station numbers, positions, etc. see Corbin (I947), Figs. I and 2, pp. 67-8 and pp. I24-32.

No post-larvae were caught more than about 60 miles from land. They occurred in the eastern part of the Celtic Sea-at the western end of the English Channel and off the St George's and Bristol Channels-and not in the western area towards the edge of the Continental Shelf. The post-larvae 
of lanceolatus (Text-figs. 2 and 3) and Ammodytes species IV (Text-fig. 6) were present throughout this region extending from south-west Ireland to the Brest Peninsula. The small number of tobianus post-larvae (ten specimens)

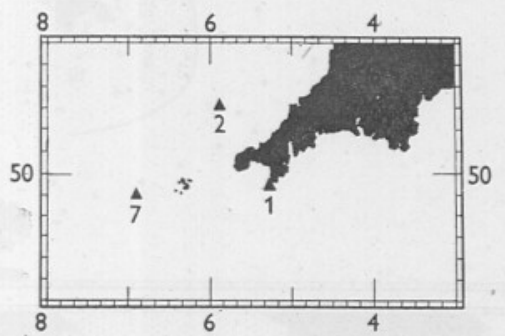

Text-fig. 4. Distribution of post-larval Ammodytes tobianus in the Celtic Sea in I937-39. April 1937, Station 34 (one specimen); April I938, Station 49 (two specimens); May-June I938, Station II (seven specimens).
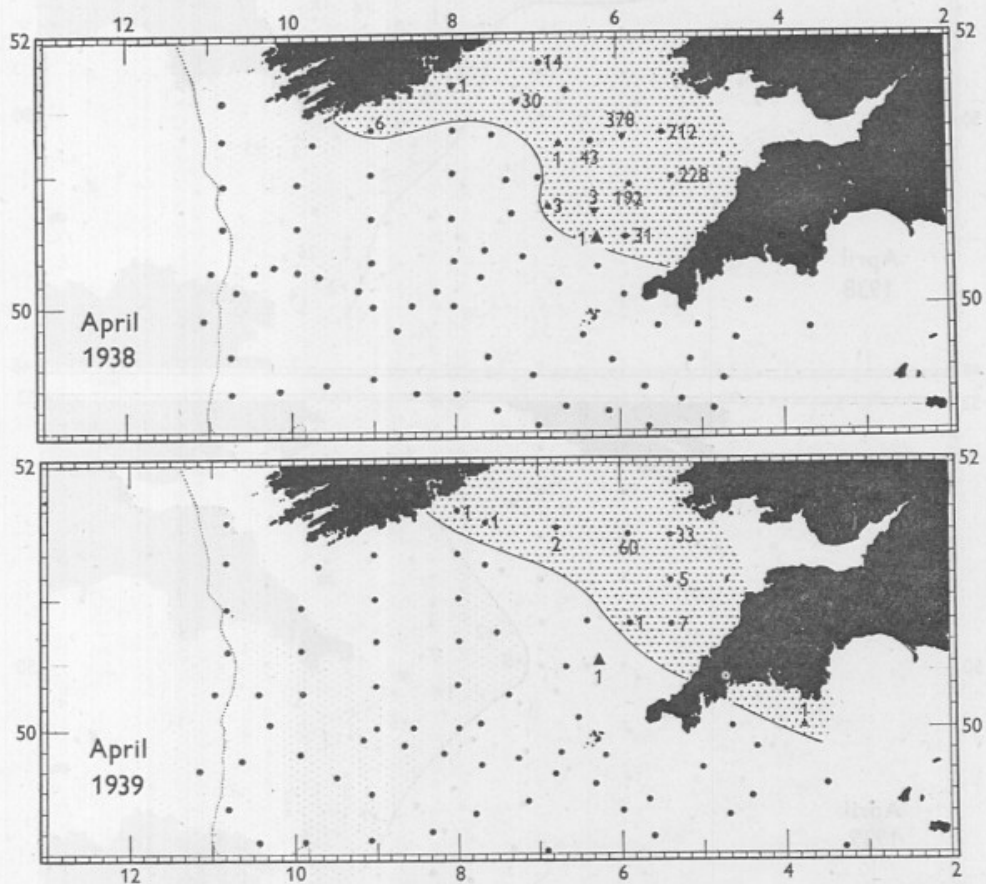

Text-fig. 5. Distribution of post-larval Ammodytes marinus in the Celtic Sea and Plymouth area in 1937-39. Figures refer to the number of post-larvae caught at each station. Station 32 of the April 1937 cruise, at which a single specimen was taken, is marked on both charts of this text-fig.

were all taken fairly close to land (Text-fig. 4). The distribution of marinus post-larvae was peculiarly restricted (Text-fig. 5). All specimens, with the exception of one taken off Plymouth (St. 62, April 1939), were caught in the 

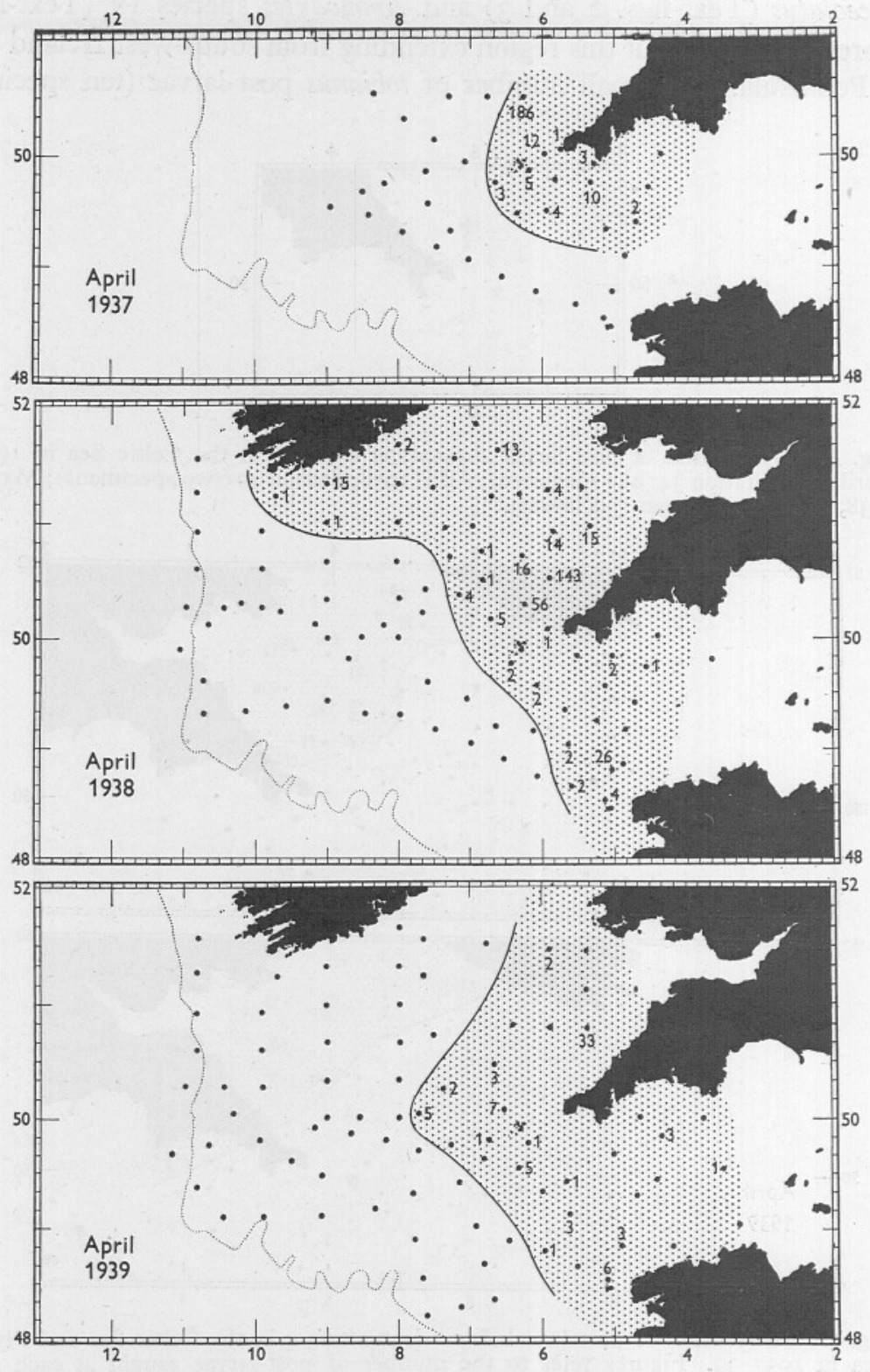

Text-fig. 6. Distribution of post-larval Ammodytes species IV in the Celtic Sea and Plymouth area in 1937-39. Figures refer to the number of post-larvae caught at each station. 
north-eastern area-off the St George's and Bristol Channels. On the April I938 and 1939 cruises, the species thus appeared to have a southerly limit of distribution along a line joining south-west Ireland and Land's End. The occurrence of only a single marinus post-larva on the April 1937 cruise is in agreement with this. It was taken about 35 miles north-west of Land's End (shown $\boldsymbol{\Delta}$ in both charts of Text-fig. 5), just on the southern limit of the marinus post-larva area of the April I 938 and 1939 cruises. All other stations of the April 1937 cruise were outside - to the south and west of - the 1938-39 marinus boundary. The presence each year of marinus post-larvae in the I930-37 collections from the Plymouth area reveals, however, that they regularly occur there and confirms the single specimen taken off Plymouth (St. 62) on the April 1939 cruise. Kändler (194I) states that it may be concluded that the dispersal area of marinus ranges as far as the western end of the English Channel. It will be of interest to know from further observations whether the southern limit indicated by the April I937-39 cruises should be continued across the western end of the English Channel from Land's End to, say, the Channel Islands. This would include the Plymouth area, but not the Land's End-Ushant region of the Channel mouth where none was taken at the numerous stations worked during the April 1937-39 cruises.

\section{SUMMARY}

The post-larval sand-eels (Ammodytidae) occurring in the Celtic Sea and Plymouth area are identifiable as Ammodytes lanceolatus, $A$. tobianus, $A$. marinus (not previously recorded from the area), and a fourth species of Ammodytes, the adult of which, it is concluded, is not yet known.

Adult Gymnammodytes semisquamatus (not previously recorded from the Plymouth area), the young of which are not yet known, increases the number of species in the area to five.

\section{REFERENCES}

Acloque, A., 1900. Faune de France. Tome I. Mammifères, Oiseaux, Poissons, Reptiles, Babaciens, Protochordes. Paris I900, pp. I-540.

BAL, D. V., I944. A study of fish eggs and larvae from Manx waters. II. Observations on the fish larvae. F. Univ. Bombay, Vol. xII, Pt. v, pp. I4-4I.

BruUn, A. F., I94I. Observations on north Atlantic fishes. 2. The Ammodytes lancea group. Vidensk. Medd. naturh. Foren., Bd. I04, pp. 329-40.

Buen, F. DE, I935. Fauna Ictiológica. Catálogo de los peces Ibéricos: aguas dulces, pelágicos y de los abismos próximos. Primera parte. Notas Inst. esp. Oceanog., No. 88 , pp. I-I 49 .

CLARK, R. S., I920. The pelagic young and early bottom stages of teleosteans. Fourn. Mar. Biol. Assoc., Vol. xII, pp. 159-240.

Collett, R., I904. Meddelelser om Norges Fiske i Aarene I884-I90I. (3die Hovedsupplement til 'Norges Fiske') II. Forh. VidenskSelsk. Krist. I903, No. 9, pp. I-I 75 . 
Corbin, P. G., 1947. The spawning of mackerel, Scomber scombrus L., and pilchard, Clupea pilchardus Walbaum, in the Celtic Sea in 1937-39. Fourn. Mar. Biol. Assoc., Vol. xxviI, pp. 65-132.

DAY, F., I880-84. The Fishes of Great Britain and Ireland, London I880-84, Vol. I, pp. $\mathrm{I}-336$.

DunCKer, G. \& Mohr, E., I935. Die nordeuropäischen Ammodytes-Arten des Hamburger Zoologischen Museums. Zool. Anz., Bd. Iro, pp. 216-20.

— 1939. Revision der Ammodytidae. Mitt. zool. Mus. Berl., Bd. 24, Heft I, pp. 8-3I.

EhrenBAuM, E., I904. Eier und Larven von Fischen der deutschen Bucht. III. Fische mit festsitzenden Eiern. Wiss. Meeresuntersuch., Bd. vI, Abt. Helgoland, Heft 2, pp. $127-200$.

- I909. Eier und Larven von Fischen. Nord. Plankt., Bd. I, Teil II, pp. 217-4I4.

Ehrenbaum, E. \& Strodtmann, S., I904. Eier und Jugendformen der Ostseefische. I. Bericht. Wiss. Meeresuntersuch., Bd. vi, Abt. Helgoland, Heft I, pp. 57-I26.

FAGE, L., I9I8. Shore fishes. Rep. Danish oceanogr. Exped. Medit., No. 4, Vol. II (Biology), A. 3, pp. I-I54.

ForD, E., I920. The post-larval stages of Ammodytes species captured during the cruises of S.S. Oithona in Plymouth waters in the year 1919. Fourn. Mar. Biol. Assoc., Vol. xII, pp. 24I-48.

Gonçalves, B. C., I942. Colecção oceanográfica de D. Carlos I. Catálogo dos peixes. Trav. Sta. Biol. marit. Lisbonne, No. 46, pp. I-I08.

GrIEG, J. A., I9I2. Icthyologiske notiser III. Bergens Mus. Aarb., I9I I, Nr. 6, pp. I-38.

GüNTHER, A., I867. Additions to the British Fauna. Ann. Mag. nat. Hist., Vol. xx (Third Series), Part 2, pp. 288-9r.

Jensen, A. S., I94I. On subspecies and races of the Lesser Sand Eel (Ammodytes lancea s. lat.). K. danske vidensk. Selsk. Skr., Biologiske Meddelelser, Bind xvI, Nr. 9, pp. I-33.

- 1944. On specific constancy and segregation into races in sea-fishes. $K$. danske vidensk. Selsk. Skr., Biologiske Meddelelser, Bind xIx, Nr. 8, pp. I-I9.

Joubin, L. \& Le Danors, E., I924. Catalogue illustré des animaux marins comestibles des côtes de France et des mers limitrophes avec leurs noms communs français et étrangers. I. Poissons osseux. Mém. Off. sci. tech. Pêch. marit., No. I, pp. I-220.

Jourdarn, S., I879. Sur les Ammodytes des côtes de la Manche. Revue de Sciences Naturelles, Tome I, pp. 203-IO.

KäNDLER, R., I94I. Untersuchungen über Fortpflanzung, Wachstum und Variabilität der Arten des Sandaals in Ost- und Nordsee, mit besonderer Berücksichtigung der Saisonrassen von Ammodytes tobianus L. Kieler Meeresforschungen, Band v, Heft I, pp. 45-I45.

^LÖNNBERG, E., I915. Sveriges Ryggradsdjur. 3. Kraldjur, Groddjur, Fiskar., Stockholm I915, pp. I-33I.

Moore, H. B., I937. Marine fauna of the Isle of Man. Proc. Lpool. biol. Soc., Vol. L, pp. I-293.

MOREAU, E., I891. Histoire naturelle des poissons de la France. Supplément, Paris I89I, pp. I-I44.

Poll, M., I947. Faune de Belgique. Poissons Marins, Bruxelles 1947, pp. I-452.

RAIT, D. S., I934. A preliminary account of the Sand Eels of Scottish Waters. f. Cons. int. Expl. Mer, Vol. Ix, pp. 365-72.

RAIT, D. S., r935. The occurrence of four species of Sand Eels, of economic importance, in Scottish waters, one of which is new to science. Scot. Nat., No. 2 I I, pp. $6 \mathrm{I}-62$.

* This reference has not been consulted personally. 
Russell, F. S., I930-47. On the seasonal abundance of young fish. Parts I-VIII. Fourn. Mar. Biol. Assoc., Vols. XvI, pp. 707-22; xx, pp. I47-79 and pp. 595-604; XXI, pp. 679-86; XXII, pp. 493-500; XxIII, pp. 38I-6; XxIv, pp. 265-70; XXVI, pp. 605-8.

Soleim, P.A., I945. A contribution to the knowledge of the Lesser Sandeel (Ammodytes lancea) in north-European waters. Rep. Norweg. Fish. Invest., Vol. vIII, No. I, pp. $\mathrm{I}-28$.

WollebeK, A., 1924. Norges Fisker., Kristiania I924, pp. I-239.

\section{APPENDIX}

The earlier work of Ehrenbaum \& Strodtmann (1904) and Ehrenbaum (I904, 1909) on the larvae and post-larvae of Ammodytes contains several errors of identification, due in part to the fact that $A$. marinus and its young stages were unknown at the time. The following notes attempt to correct the misidentifications. Corrections already made by Ford (I920) and Kändler (I94I) are also included.

\section{Ehrenbaum \& Strodtmann (1904)}

Fig. 8, p. I04 (also Ehrenbaum (1909), Fig. I06c, p. 298), post-larva $20.5 \mathrm{~mm}$.; ascribed to A. tobianus.

Kändler (194I) points out that the pigmentation and date of capture (February) of this specimen identify it as A. marinus.

\section{Ehrenbaum (1904), Taf. VII}

Fig. 70 (also Ehrenbaum (1909), Fig. I07a, p. 300), larva 4.2 mm. and Fig. 7I, larva $5 . \mathrm{I} \mathrm{mm}$; both ascribed to A. lanceolatus.

The specimens were reared from artificially fertilized eggs. In these circumstances it seems very unlikely that an error would have occurred in the identification of the parents of the fertilization had they been specimens of lanceolatus. Neither of the larvae, however, shows the ventral fin-membrane pigment row which is specifically characteristic of the earliest stages of lanceolatus (p. 296), and the ventral gut pigment is also very much heavier than in early lanceolatus. The pigmentation is in all respects characteristic of $A$. tobianus. Both pigmentation and date of fertilization (June) rule out $A$. marinus and Ammodytes species IV.

Fig. 72 (also Ehrenbaum (1909), Fig. 107b, p. 300), post-larva $12.5 \mathrm{~mm}$; ascribed to $A$. lanceolatus.

Ford (1920) points out, and Kändler I94I agrees with him, that the pigmentation of this specimen identifies it as $A$. tobianus.

Fig. 80 , larva $2 \cdot 2 \mathrm{~mm}$. and Fig. $8 \mathrm{I}$, larva $4.0 \mathrm{~mm}$.; both ascribed to A.tobianus.

These specimens hatched prematurely from artificially fertilized eggs. The date of fertilization (September) is therefore likely to be the only reliable criterion for identification, and indeed supports Ehrenbaum's identification. 
Fig. 82, larva $4.5 \mathrm{~mm}$.; ascribed to $A$. tobianus.

This specimen evidently resulted from the same artificial fertilization as those in figs. 80 and 8I. Ehrenbaum's identification is thus supported by the date of fertilization. This and the lack of ventral gut pigment are in agreement with Kändler's (I94I) lightly pigmented autumn-brood tobianus post-larva of the North Sea and Baltic.

Fig. 83 , larva $4.7 \mathrm{~mm}$.; ascribed to $A$. tobianus.

The specimen is figured from the dorsal side and cannot therefore be identified by its pigmentation. The date of capture (September) supports Ehrenbaum's identification.

Fig. 84 (also Ehrenbaum (I909), Fig. I06a, p. 298), larva $6.6 \mathrm{~mm}$. and Fig. 85, larva, anterior end; both ascribed to A. tobianus.

The date of capture (January) of these specimens, their pigmentation, the noticeably slender form, and particularly the length while still carrying a large oil globule (fig. $84,6.6 \mathrm{~mm}$.) are evidence that they belong to $A$. marinus.

Fig. 86 (also Ehrenbaum (1909), Fig. I06 b, p. 298), post-larva $16.2 \mathrm{~mm}$.; ascribed to $A$. tobianus.

Kändler (I94I) points out that the pigmentation is clearly that of A. marinus.

It is of interest that Ehrenbaum and Strodtmann evidently did not procure any post-larvae of $A$. lanceolatus.

\section{EXPLANATION OF PLATES I \& II}

The drawings were made from specimens preserved in formalin. All specimens are drawn to the same scale (see inset on Plates), with the exception of the specimen in PI. I, fig. $2 a$, All specimens were taken in half-hour oblique hauls of the $2 \mathrm{~m}$. stramin ring-trawl in the Celtic Sea or Plymouth area, with the exception of the specimen in Pl. I, fig. $2 a$.

\section{Plate I.}

Fig. I. Ammodytes lanceolatus Lesauvage

a. Post-larva 4.5 mm. Station $\mathrm{L}_{3}-\mathrm{L}_{4}$, Plymouth, I9. iii. 1937.

b. Post-larva $7.5 \mathrm{~mm}$. Eddystone, 26. iv. 1937 .

c. Post-larva $12.5 \mathrm{~mm}$. Station 48 , Celtic Sea, 25 . iv. 1939.

d. Post-larva $18.5 \mathrm{~mm}$. 4 miles SSE. of Mewstone, Plymouth, 22. vii. 1936.

e. Post-larva $26.5 \mathrm{~mm}$. Eddystone, 13. vii. 1937.

Fig. 2. Ammodytes marinus Raitt

The scale for $a$ is above the drawing. The scale for $b-h$ is below $h$.

a. Larva 6.25 mm. Station I5(I), North Sea, 24. i. I947, Cruise 3, R.V. Platessa, Hensen net, vertical.

b. Post-larva $7.5 \mathrm{~mm}$. Station 46 , Celtic Sea, I4. iv. 1938.

c. Post-larva II $\circ \mathrm{mm}$. Station 45 , Celtic Sea, I4. iv. I 938.

d. Post-larva $\mathrm{I} 4.0 \mathrm{~mm}$. Station 45 , Celtic Sea, I4. iv. I 938.

e. Post-larva $18.5 \mathrm{~mm}$. Station 48, Celtic Sea, 25. iv. I 938.

$f$. Post-larva $19.0 \mathrm{~mm}$. Station 45, Celtic Sea, 24. iv. I939.

g. Post-larva $23.0 \mathrm{~mm}$. Station 46, Celtic Sea, 25. iv. 1939.

h. Post-larva $27.5 \mathrm{~mm}$. Station 45 , Celtic Sea, 24. iv. 1939. 


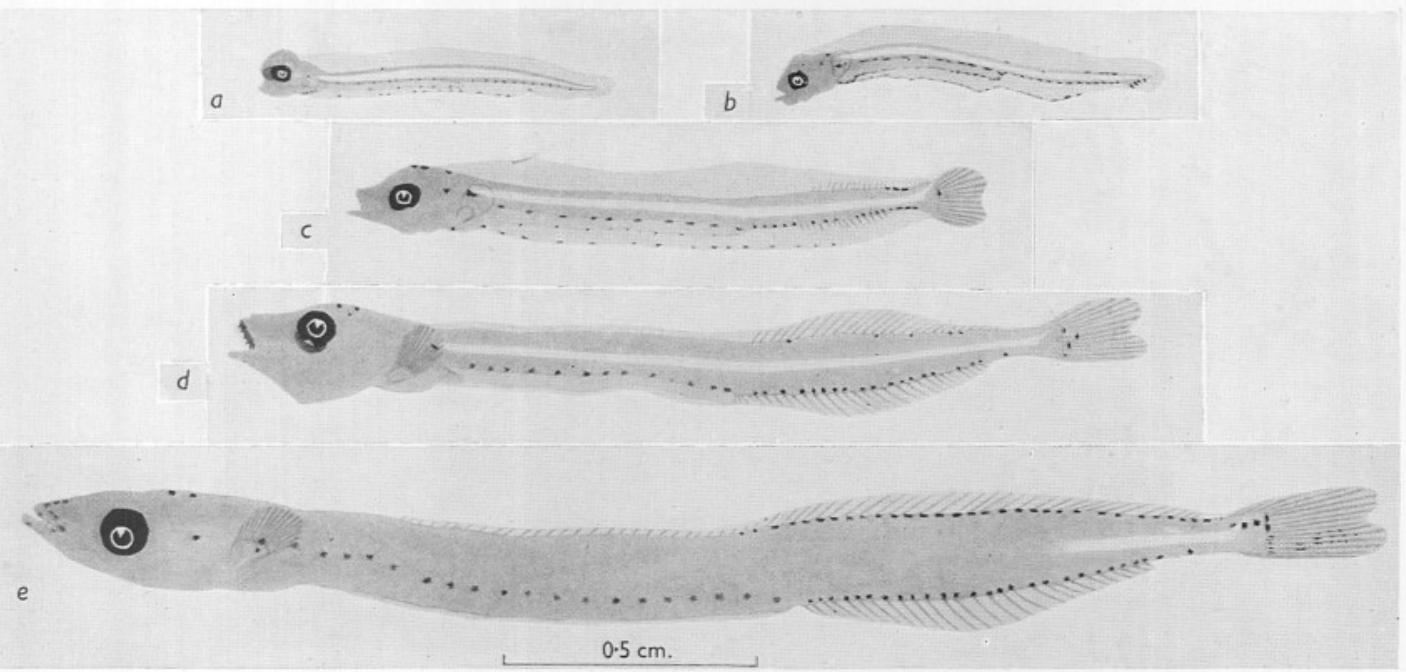

Fig. I. Ammodytes lanceolatus
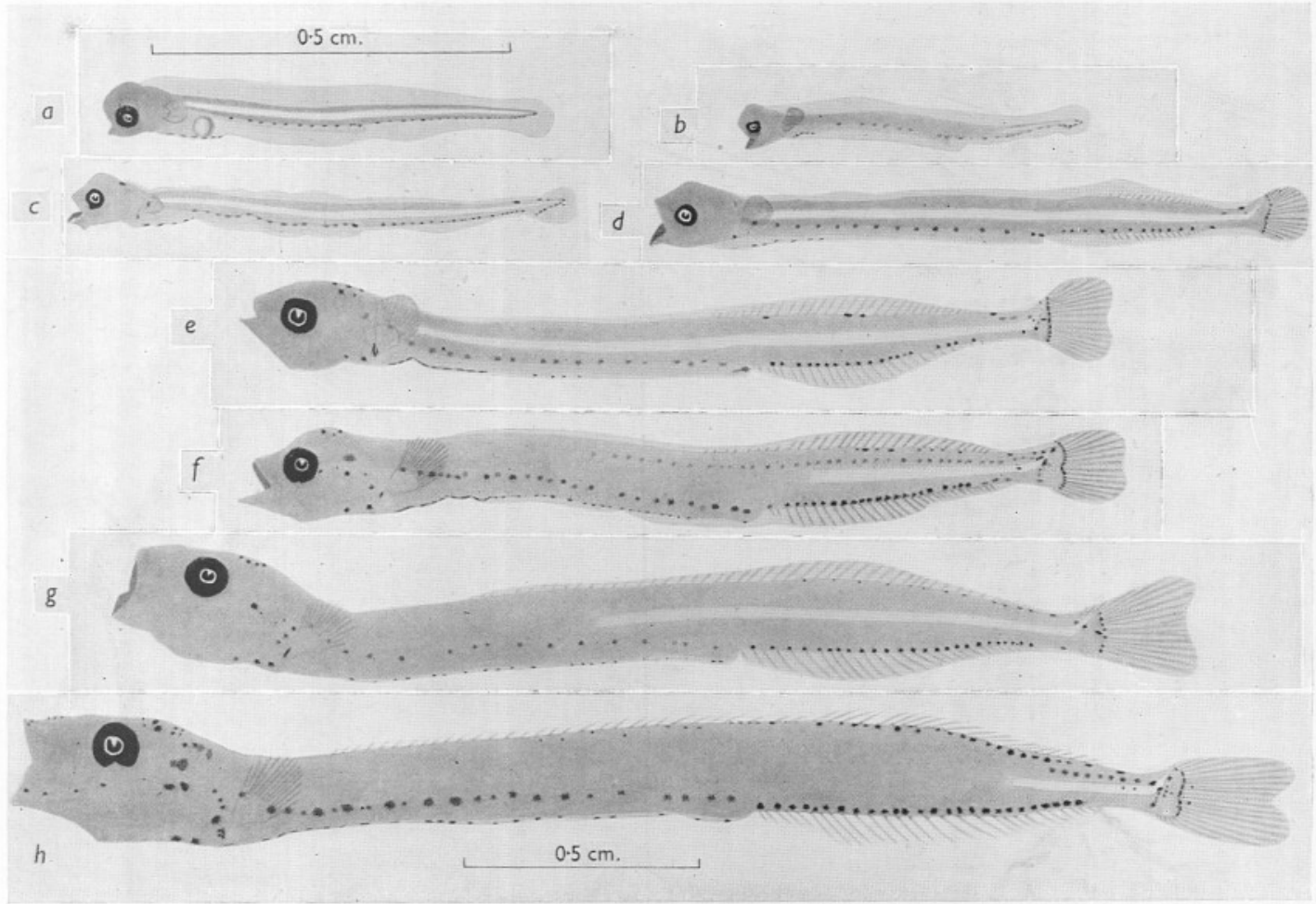

Fig. 2 Ammodytes marinus 


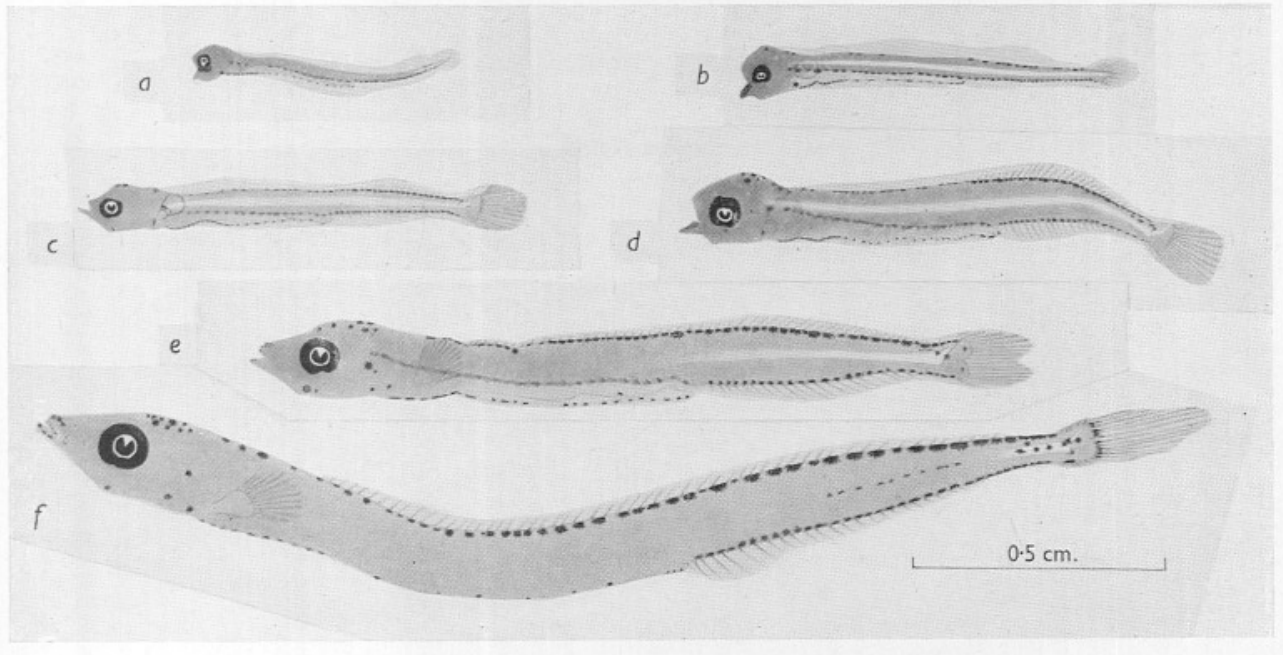

Fig. I. Ammodytes tobianus

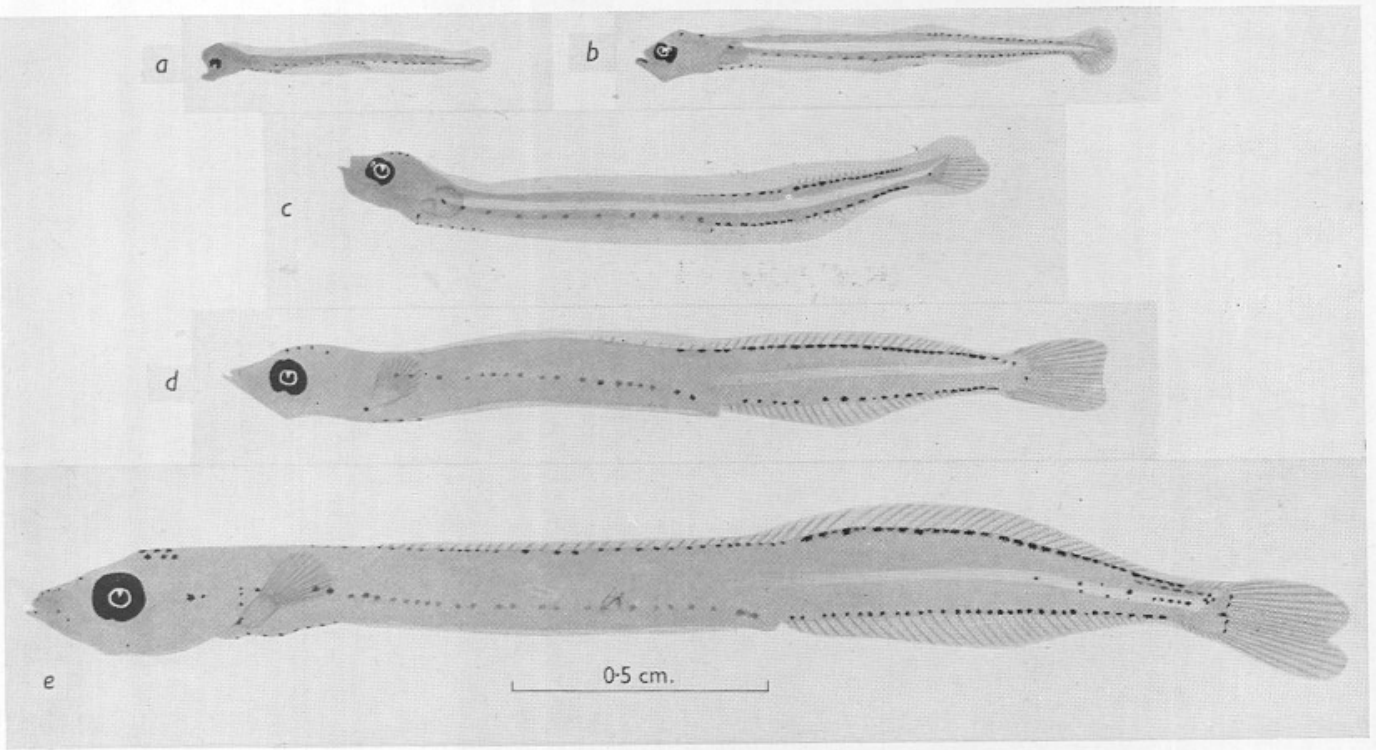

Fig. 2. Ammodytes species IV

del. V.V. 
Plate II.

Fig. I. Ammodytes tobianus L.

a. Post-larva $5.25 \mathrm{~mm}$. Station II, Celtic Sea, 2. vi. 1938.

b. Post-larva $8.0 \mathrm{~mm}$. Station II, Celtic Sea, 2. vi. 1938 .

c. Post-larva $8.75 \mathrm{~mm}$. Eddystone, II. viii. 1936 .

d. Post-larva Ir $0 \mathrm{~mm}$. Eddystone, 24. vi. 1947.

e. Post-larva $15.5 \mathrm{~mm}$. Eddystone, 9. x. 1935 .

f. Post-larva $23.0 \mathrm{~mm}$. Eddystone, 7. viii. 1930 .

Fig. 2. Ammodytes species IV

a. Post-larva $5.5 \mathrm{~mm}$. Bolt Head E. $\times$ S.: Stoke Point N., Plymouth, 27. i. 1937.

b. Post-larva $9 \cdot 0 \mathrm{~mm}$. Station 33, Celtic Sea, 20. iv. 1937.

c. Post-larva $13.0 \mathrm{~mm}$. Station 33, Celtic Sea, 20. iv. I937.

d. Post-larva $17.5 \mathrm{~mm}$. Station 40, Celtic Sea, 23. iv. I939.

e. Post-larva $26.0 \mathrm{~mm}$. Station 5I, Celtic Sea, 25. iv. 1939. 